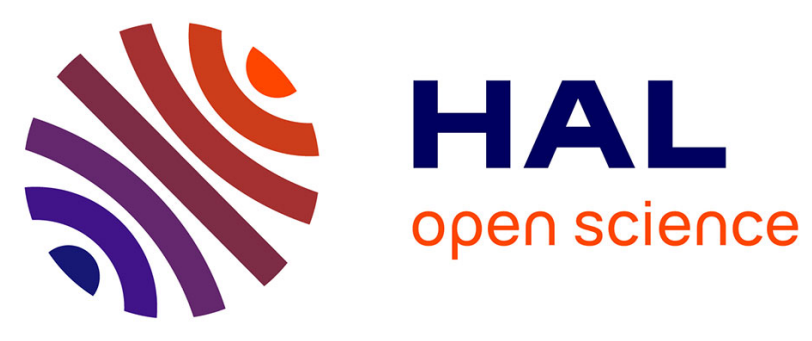

\title{
The Mi-EFF1/Minc17998 effector interacts with the soybean GmHub6 protein to promote host plant parasitism by Meloidogyne incognita
}

Reneida Aparecida Godinho Mendes, Marcos Fernando Basso, Bruno Paes de

Melo, Thuanne Pires Ribeiro, Rayane Nunes Lima, Janaina Fernandes de Araújo, Maira Grossi-De-Sa, Vanessa da Silva Mattos, Roberto Coiti Togawa, Érika Valéria Saliba Albuquerque, et al.

\section{- To cite this version:}

Reneida Aparecida Godinho Mendes, Marcos Fernando Basso, Bruno Paes de Melo, Thuanne Pires Ribeiro, Rayane Nunes Lima, et al.. The Mi-EFF1/Minc17998 effector interacts with the soybean GmHub6 protein to promote host plant parasitism by Meloidogyne incognita. Physiological and Molecular Plant Pathology, 2021, 114, pp.101630. 10.1016/j.pmpp.2021.101630 . hal-03451678

\section{HAL Id: hal-03451678 \\ https://hal.inrae.fr/hal-03451678}

Submitted on 26 Nov 2021

HAL is a multi-disciplinary open access archive for the deposit and dissemination of scientific research documents, whether they are published or not. The documents may come from teaching and research institutions in France or abroad, or from public or private research centers.
L'archive ouverte pluridisciplinaire $\mathbf{H A L}$, est destinée au dépôt et à la diffusion de documents scientifiques de niveau recherche, publiés ou non, émanant des établissements d'enseignement et de recherche français ou étrangers, des laboratoires publics ou privés. 


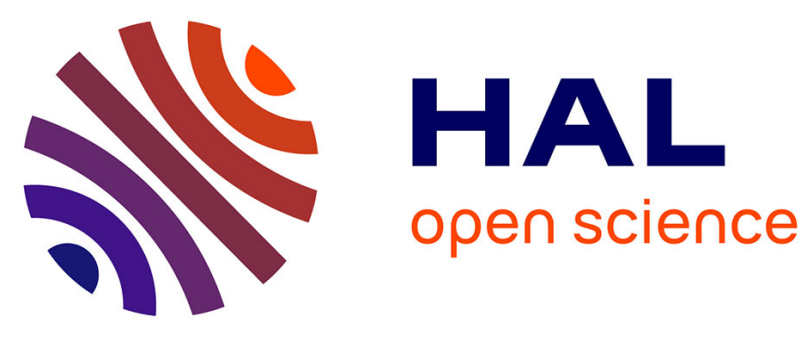

\section{The Mi-EFF1/Minc17998 effector interacts with the soybean GmHub6 protein to promote host plant parasitism by Meloidogyne incognita}

Reneida Aparecida Godinho Mendes, Marcos Fernando Basso, Bruno Paes De

Melo, Rayane Nunes Lima, Janaina Fernandes De Araújo, Maira Grossi

De-Sa, Vanessa da Silva Mattos, Roberto Coiti Togawa, Érika Valéria Saliba

Albuquerque, Maria Eugênia Lisei De-Sa, et al.

\section{- To cite this version:}

Reneida Aparecida Godinho Mendes, Marcos Fernando Basso, Bruno Paes De Melo, Rayane Nunes Lima, Janaina Fernandes De Araújo, et al.. The Mi-EFF1/Minc17998 effector interacts with the soybean GmHub6 protein to promote host plant parasitism by Meloidogyne incognita. 2020. hal03052406

\section{HAL Id: hal-03052406 \\ https://hal.archives-ouvertes.fr/hal-03052406}

Preprint submitted on 10 Dec 2020

HAL is a multi-disciplinary open access archive for the deposit and dissemination of scientific research documents, whether they are published or not. The documents may come from teaching and research institutions in France or abroad, or from public or private research centers.
L'archive ouverte pluridisciplinaire HAL, est destinée au dépôt et à la diffusion de documents scientifiques de niveau recherche, publiés ou non, émanant des établissements d'enseignement et de recherche français ou étrangers, des laboratoires publics ou privés. 


\section{The Mi-EFF1/Minc17998 effector interacts with the soybean GmHub6 protein to promote host plant parasitism by Meloidogyne incognita}

\section{Reneida Aparecida Godinho Mendes}

Empresa Brasileira de Pesquisa Agropecuaria Recursos Geneticos e Biotecnologia Marcos Fernando Basso ( $\square$ marcosbiotec@gmail.com )

Empresa Brasileira de Pesquisa Agropecuaria Recursos Geneticos e Biotecnologia https://orcid.org/0000-0001-8192-8959

\section{Bruno Paes de Melo}

Empresa Brasileira de Pesquisa Agropecuaria Recursos Geneticos e Biotecnologia

Rayane Nunes Lima

Empresa Brasileira de Pesquisa Agropecuaria Recursos Geneticos e Biotecnologia Janaina Fernandes de Araújo

Empresa Brasileira de Pesquisa Agropecuaria Recursos Geneticos e Biotecnologia Maira Grossi de-Sa

Empresa Brasileira de Pesquisa Agropecuaria Recursos Geneticos e Biotecnologia Vanessa da Silva Mattos

Empresa Brasileira de Pesquisa Agropecuaria Recursos Geneticos e Biotecnologia Roberto Coiti Togawa

Empresa Brasileira de Pesquisa Agropecuaria Recursos Geneticos e Biotecnologia Érika Valéria Saliba Albuquerque

Empresa Brasileira de Pesquisa Agropecuaria Recursos Geneticos e Biotecnologia Maria Eugênia Lisei de-Sa

Empresa Brasileira de Pesquisa Agropecuaria Recursos Geneticos e Biotecnologia Maria Cristina Mattar da Silva

Empresa Brasileira de Pesquisa Agropecuaria Recursos Geneticos e Biotecnologia

Leonardo Lima Pepino Macedo

Empresa Brasileira de Pesquisa Agropecuaria Recursos Geneticos e Biotecnologia

Rodrigo da Rocha Fragoso

Empresa Brasileira de Pesquisa Agropecuaria Cerrados

Diana Fernandez

CIRAD

Florence Vignols

Biochimie et Physiologie Moleculaire des Plantes 
Maria Fatima Grossi-de-Sa

Empresa Brasileira de Pesquisa Agropecuaria Recursos Geneticos e Biotecnologia

\section{Research article}

Keywords: Root-knot nematodes, effector secretion, protein-protein interaction, nematode control

DOI: https://doi.org/10.21203/rs.3.rs-29152/v1

License: (c) (i) This work is licensed under a Creative Commons Attribution 4.0 International License. Read Full License 


\section{Abstract}

Background: Meloidogyne incognita is the most frequently reported species from the root-knot nematode (RKN) complex responsible for causing damage in several different crops worldwide. The interaction between $M$. incognita and host plants involves the secretions of molecular factors from the nematode, which mainly suppress the defense response and promote plant parasitism. On the other hand, several plant elements are associated with the immune defense system that opposes nematode infection.

Results: In this study, the interaction of the Mi-EFF1/Minc17998 effector with the soybean GmHub6 (Glyma.17G099100; TCP14) protein was identified and characterized in vitro and in vivo. Data showed that the GmHub6 gene is upregulated by $M$. incognita infection in a nematode-resistant soybean cultivar (PI595099) compared to a susceptible cultivar (BRS133). Accordingly, the Arabidopsis thaliana AtHub6 mutant line (AT3G47620, orthologous gene of GmHub6 displayed normal vegetative development of the plant but was more susceptible to $M$. incognita. Thus, since the soybean and $A$. thaliana Hub6 proteins are TEOSINTE BRANCHED/CYCLOIDEA/PCF (TCP) transcription factors involved in plant development and morphogenesis modulation, flowering time regulation, and the activation of the plant immune system, our data suggest that the interaction of Mi-EFF1/Minc17998 and Hub6 proteins is associated with an increase in plant susceptibility to nematode infection during parasitism. It is suggested that this interaction may prevent the nuclear localization or disturb the activity of GmHub6 as a typical transcription factor modulating the cell cycle of the plant, avoid the activation of the host's defense response, and successfully promote parasitism.

Conclusion: Our findings indicate the potential of the Mi-EFF1/Minc17998 effector for the development of biotechnological tools based on the approaches of RNA interference and GmHub6 gene overexpression for RKN control.

\section{Background}

Meloidogyne incognita is a biotrophic pathogen and obligate sedentary endoparasite belonging to the root-knot nematode (RKN) complex, which consists of the unique genus Meloidogyne spp. [1, 2]. The RKN life cycle consists of six stages: egg, J1 (first-stage juvenile), J2 (second-stage juvenile), J3 (third-stage juvenile), J4 (fourth-stage juvenile), and adult (female and male). J3, J4, and female individuals are typically sedentary endophytes, while the egg, $\mathrm{J} 1$, and preparasitic $\mathrm{J} 2$ stages are exophytes in most Meloidogyne species [2-4]. M. incognita is one of the major agricultural pathogens responsible for causing significant annual economic losses worldwide [5]. It disturbs plant roots by altering the cell cycle, increasing the size of parasitized cells, and causing cell hyperproliferation and the development of giant cells [6-10]. These disorders disrupt water and nutrient uptake in roots and may reduce plant growth and yield [11-13].

The interaction between $M$. incognita and host plants involves an extensive molecular immunity network involved in defense and counter-defense $[14,15]$. In addition to basal defense mechanisms, after the 
recognition of nematode elicitors, host plants increase the production of reactive oxygen and nitrogen species and other toxic compounds derived from secondary metabolism [16-19]. In contrast, $M$. incognita increases the production and release of antioxidant and detoxifying compounds [20-23] and, particularly, effector proteins to overcome host defense [24-26]. Thus, several nematode effector proteins modulate different biological processes and defense responses of the host plant [24, 26-30]. For example, MiMSP18 [28] and Mi-Msp40 [31] effectors function in cell death suppression and can increase plant susceptibility and modulate host immunity. Likewise, the Mi-Mi8D05 effector interacts with the plant tonoplast intrinsic protein 2 (TIP2) aquaporin, suggesting that it regulates solute and water transport within giant cells [32]. Other examples include Mi-MiPFN3, which disrupts the plant's actin cytoskeleton [33], while Mi-MiMIFs interfere with annexin-mediated plant immune responses [30] to promote plant infection.

In this context, secretome analyses of $M$. incognita J2 preparasites allowed the identification of numerous candidate effector proteins [20,34-36], but their roles in host parasitism are still not well understood. By applying comparative genomic approaches to EST datasets, Jaouannet et al. [37] identified at least three genes that were specifically expressed in the esophageal glands of parasitic $M$. incognita juveniles. Among these genes, the Mi-EFF1/Minc17998 effector is secreted during parasitism within giant cells and is targeted to the nuclei. Therefore, the Mi-EFF1/Minc17998 effector has been suggested to be involved in the manipulation of the nuclear functions of the host cells [37]. Nevertheless, the precise role of this effector during plant parasitism has not yet been demonstrated. Previous studies on protein-protein interactions between Arabidopsis thaliana and different phytopathogens (bacteria, oomycetes, and fungi) showed that several pathogen effector proteins preferentially interact with a limited set of highly connected (hub) proteins of the host plant [38-40]. AtHub6 (AT3G47620), the most targeted hub protein, was shown to interact with four effectors of the bacterium Pseudomonas syringae, 25 effectors of the oomycete Hyaloperonospora arabidopsidis [38], and 23 effectors from the fungus Golovinomyces orontii [39]. Interestingly, AtHub6 is a TEOSINTE BRANCHED/CYCLOIDEA/PCF (TCP) 14 (AtTCP14) transcription factor that transcriptionally activates or interacts with numerous other plant proteins associated with cell cycle control, plant development [41-46], and regulation of the immune system [38, 42, 47-49]. Curiously, Yang et al. [48] showed that the $P$. syringae HopBB1 effector interacts with the AtTCP14 protein and targets it to the $\mathrm{SCF}^{\mathrm{CO} 11}$ degradation complex, thus promoting bacterial virulence. Similarly, the $A$. thaliana triple T-DNA insertion mutant for the AtTCP8, AtTCP14, and AtTCP15 genes (tcp8, tcp 14, and tcp15) proved to be more susceptible to $P$. syringae pv. maculicola than wild-type (WT) plants [47]. Additionally, Spears et al. [43] demonstrated that the A. thaliana tcp8 tcp 14 tcp 15 triple mutant exhibited impairment of pathogen-associated molecular pattern (PAMP)-triggered immunity (PTI), which is one layer of the plant innate immune system. Despite its involvement in plant developmental and defense responses, there is no information about the interaction of AtHub6 with nematode effectors and the role of these protein-protein interactions in plant susceptibility to nematode infection.

Soybean (Glycine max) is one of the most important agricultural commodities worldwide and is indispensable for human and animal nutrition [50,51]. However, soybean crop expansion and yields have 
been limited by nematode incidence [52]. The main commercial soybean cultivars are highly susceptible to nematode infections, and under inefficient nematode management, significant yield and economic losses are caused annually by RKNs, including $M$. incognita [53]. Thus, a better understanding of the molecular interactions between soybean and nematodes may allow the development of new biotechnological tools (NBTs) for RKN control $[54,55]$. Herein, we identified and validated the interaction between the Mi-EFF1/Minc17998 effector and the soybean GmHub6 protein (orthologue of AtHub6) using in vitro and in vivo approaches. Curiously, our data obtained using an $A$. thaliana T-DNA mutant of the AtHub6 gene suggested that the disruption of AtHub6 protein function can be associated with an increase in plant susceptibility to nematode infection. Therefore, our data strongly indicate that this interaction can modulate the development of parasitized cells, prevent the activation of the immune system and, consequently, support the parasitism of the host plant.

\section{Results}

\section{In silico analysis of the Mi-EFF1/Minc17998 effector sequence}

Pairwise comparisons of nucleotide and amino acid sequences showed that the Mi-EFF1/Minc17998 effector shares low sequence identity with other effectors that are currently better characterized, ranging from 50 to $75 \%$ (Fig. 1A) and 15 to 35\% (Fig. 1B), respectively. In addition, it has been observed that the Mi-EFF1/Minc17998 effector exhibits relatively conserved orthologous genes in the other species of the Meloidogyne genus (Figure S1). A paralogous gene for the Mi-EFF1/Minc17998 effector identified (Minc3s01563g24741) in the M. incognita genome (BioProject PRJEB8714, [56] showed considerable homology with its corresponding Mi-EFF1/Minc17998 gene (Figure S1). Phylogenetic analysis based on nucleotide sequences showed that the Mi-EFF1/Minc17998 effector clustered with the MiPFN3 and MjNULG1a effectors (Fig. 1C), while amino acid sequence analysis showed that the effector grouped most closely to the Minc00469 and MilSE5 effectors (Fig. 1D). These data obtained from sequence comparisons and the analysis of phylogenetic relationships suggest that the Mi-EFF1/Minc17998 effector does not exhibit a well-defined origin or conserved relationships with other nematode effectors. Transcriptome data mining revealed the expression profiles of the Mi-EFF1/Minc17998 effector and the Minc3s01563g24741 gene paralog in different nematode life stages. The two genes showed similar expression levels, with higher expression in the $\mathrm{J} 3, \mathrm{~J} 4$, and female stages, while expression was lower in the egg and preparasitic J2 stages (Fig. 1E). RT-qPCR assays revealing the Mi-EFF1/Minc17998 effector expression profile confirmed that expression was higher in the $\mathrm{J} 2 / \mathrm{J} 3, \mathrm{~J} 3 / \mathrm{J} 4$, and female stages, but significant expression was also observed in the egg and J2 stages (Fig. 1F). These data showed that MiEFF1/Minc17998 gene expression is closely associated with the infection stages in the host plant.

\section{The Mi-EFF1/Minc17998 effector interacts with the soybean GmHub6 protein}

In this study, eight of the $A$. thaliana hub proteins previously identified by Mukhtar et al. [38] were selected, and their orthologous soybean genes were identified: GmHub4 (COP9 signalosome complex subunit 5), GmHub6 (TCP family transcription factor), GmHub10 (kinesin light chain), GmHub12 
(APC8/anaphase -promoting complex subunit), GmHub17 (TCP family transcription factor), GmHub42 (transcription factor UNE12-related), GmHub47 (jasmonate ZIM domain-containing protein), and GmHub61 (uncharacterized conserved protein containing an emsy amine-terminus domain) (Table 1). Soybean CDS sequences were cloned into entry and destination vectors to assess the interaction with the Mi-EFF1/Minc17998 effector by in vitro and in vivo protein-protein interaction assays. Yeast two-hybrid $(\mathrm{Y} 2 \mathrm{H})$ assays were performed with the soybean proteins and Mi-EFF1/Minc17998, and specific proteinprotein interactions were observed only with the GmHub6 protein (Fig. 2A). The Mi-EFF1/Minc17998 effector showed specific interaction with the GmHub6 protein in both $\mathrm{Y} 2 \mathrm{H}$ (Fig. $2 \mathrm{~B}$ and $\mathrm{C}$ ) and in vivo by bimolecular fluorescence complementation (BiFC) assays in tobacco (Nicotiana tabacum) (Fig. 2D). In addition, both Mi-EFF1/Minc17998 and the GmHub6 protein showed an autoactivation ability (Fig. 2B). The Mi-EFF1/Minc17998 and GmHub6 interaction was considered a relatively weak interaction based on the results of the addition of the 3AT competitive inhibitor to selective medium (Fig. 2C).

\section{In silico characterization of the soybean GmHub proteins}

All eight GmHub proteins studied here showed transcript accumulation in almost all plant tissues tested (Figure S2A to S2B). In addition, their protein-protein interaction networks were distinct, except for GmHub10 and GmHub12, which simultaneously interacted with Glyma.07G190600 (anaphase-promoting complex 4) (Figure S2C). GmHub6 and its homologous gene (Glyma.05G027400) showed higher amino acid identity with AtHub6 (approx. 55\%) and SITCP14 (approx. 70\%), while lower sequence identity (approx. 25\%) was observed with other soybean GmHub proteins except for GmHub17 (Fig. 3A). In addition, phylogenetic analysis using amino acid sequences showed that GmHub6 and its homologous gene were grouped close to the TCP transcription factors AtHub6, GmHub17, and SITCP14 (Fig. 3B). The biological functions of the GmHub6 protein are involved in plant development and the regulation of the defense response, and the protein contains a typical TCP domain (pfam03634) and nuclear localization signal (Tables 1 and 2; Additional file 1). The protein-protein interaction network retrieved from the STRING database highlighted that GmHub6 is the core protein that interacts with numerous other proteins (Figure S3A) similar to the AtHub6 network (Figure S3B). These proteins from the GmHub6 network include several other TCP proteins (Table 2), but considering the orthology with AtHub6, this network of interactions maybe even larger, including dozens of proteins with highly distinct functions [38]. Curiously, GmHub6 transcripts accumulated in almost all soybean tissues and all different conditions examined, with very low accumulation being observed in the nodules under symbiotic conditions, roots under ammonia treatment, youngest roots, and seeds, in contrast to the relatively high abundance observed in leaves (Figure S3C). In addition, the GmHub6 gene showed a positive correlation at the expression level with the Glyma.01G014900, Glyma.16G004300, and Glyma.18G296100 genes from its network in the same soybean tissues or conditions (Figure S3D).

\section{GmHub6 expression profile in soybean roots during $M$. incognita infection}

RT-qPCR assays showed that the GmHub6 gene was upregulated in the axillary roots during nematode infection (at 3 dpi) only in the nematode-resistant soybean cultivar PI595099 (Fig. 3C). However, the 
GmHub6 expression level was similar in the noninoculated roots of both the resistant and susceptible soybean cultivars. In contrast, a higher expression level of the GmHub6 gene was observed at 25 dpi in the resistant cultivar in both mock-treated and inoculated roots. With respect to the GmHub6 expression level in the four developmental stages (stage I, II, III, and IV) of the soybean plants, significant differences were observed from stage I to stage IV in both soybean cultivars. Thus, in both mock-inoculated and infected plants, the GmHub6 gene expression level was finely modulated throughout plant development, which was more pronounced in the resistant soybean cultivar, mainly as a consequence of nematode infection.

\section{M. incognita susceptibility assessment of the $A$. thaliana AtHub6 mutant}

A. thaliana AtHub6 mutant plants showed normal development, similar to that of the WT plants (data not shown). To assess whether the interaction of the Mi-EFF1/Minc17998 effector with the soybean GmHub6 protein may be associated with an increase in plant susceptibility, the AtHub6 mutant was inoculated with $250 \mathrm{M}$. incognita J2 individuals, and the evolution of parasitism was evaluated over time. The nematode penetration efficiency, post penetration development, and formation and morphology of the galls in AtHub6 mutant plants were similar to those in the WT and AtEds 1 control plants (data not shown). However, at $40 \mathrm{dpi}$, the AtHub6 plants showed a greater number of eggs and $\mathrm{J} 2$ individuals per gram of roots, a similar number of galls per gram of roots, and a higher nematode reproduction factor (NRF) compared with the WT and AtEds 1 mutant plants (Fig. 3D to 3G). These data indicate that plants in which the AtHub6 gene was mutated were more susceptible to the nematode.

\section{Discussion}

Plants exhibit numerous mechanisms associated with defense against pathogens that are regulated in the presence or absence of pathogens to prioritize the development of the plant or the defense response [57-59]. The growth defense trade-off is essential to ensure plant survival and reproduction [60]. The development and defense pathways are closely related so that any disturbance in the cell cycle can trigger the plant immune system [61, 62]. Initially, the root damage caused by RKN infection releases plant-derived compounds that act as damage-associated molecular patterns (DAMPs) and subsequently activate a PTI-like basal defense response [63]. Another step in PTI against RKNs may involve the recognition of PAMPs or nematode-associated molecular patterns (NAMPs), including ascarosides, cuticle, or chitin fragments [64].

In addition to inactivating host defenses, RKNs also need to modulate the cell cycle of the host plant for the successful establishment of a feeding site $[8,65,66]$. The RKNs are sedentary endoparasitic pathogens that spend most of their life cycle inside the roots and giant cells from $\mathrm{J} 2$ entry to oviposition by adult females. This infective phase usually lasts approximately 20 to 35 days for $M$. incognita, and effector proteins are essential to nematode infection $[67,68]$. Since the first $M$. incognita genome sequence was reported $[2,56]$, several effector proteins have been identified, and some have been 
characterized, but their role after their secretion in the host plant cell is still poorly understood $[15,20,34$, 69].

In this study, we have contributed to the knowledge of the functional characteristics of the MiEFF1/Minc17998 effector and proposed a role of this effector in the parasitism of the host plant. Jaouannet et al. [37] and Quentin et al. [70] demonstrated that this effector is produced in the esophageal glands of parasitic juveniles, secreted within the feeding site and targeted to the nucleus, suggesting its involvement in the modulation of host cell metabolism. Herein, we showed that this effector presents low sequence identity and distant phylogenetic relationships with other well-known effectors, suggesting a specific mode of action after delivery in the host plant. In addition, our data showed that the $\mathrm{Mi}$ EFF1/Minc17998 gene is strongly upregulated during parasitism in the $\mathrm{J} 2 / \mathrm{J} 3, \mathrm{~J} 3 / \mathrm{J} 4$, and female stages but is also expressed in eggs and preparasitic $\mathrm{J} 2$ individuals, suggesting the role of its product as a putative avirulence protein and its involvement in the formation of giant cells. A specific protein-protein interaction between Mi-EFF1/Minc17998 and the soybean GmHub6 protein was demonstrated, and the functional disruption of the GmHub6 protein has been speculated to occur in the context of plant parasitism. Considering that the GmHub6 protein could play an essential role similar to that of AtHub6/TCP14 in the regulation of the cell cycle, plant growth and development [41-46] and the regulation of the plant's defense responses [38, 42, 47-49], this speculation is quite plausible. Accordingly, several molecular interactions between nematode effectors and host plant proteins have already been characterized and associated with cell cycle modulation [8,65] and host defense suppression [25, 30, 69, 71-73]. In our study, the data on the EFF1/Minc17998 effector and GmHub6 protein interaction, together with the increased susceptibility of the AtHub6 mutant plants to $M$. incognita infection, suggest that this effector may be associated with cell cycle modulation and/or the suppression of plant defense responses. Similarly, Kim et al. [49], Li et al. [47] and Spears et al. [43] demonstrated that the A. thaliana attcp8, attcp 14, and attcp 15 triple mutant exhibited impaired immune responses, while Yang et al. [48] showed that the AtTCP14 protein was targeted for degradation after interaction with the $P$. syringae HopBB1 effector.

Stam et al. [74] showed that the Phytophthora capsici CRN12_997 effector interacts with the tomato SITCP14 (putative ortholog of the GmHub6 and AtHub6 genes) protein, reducing the SITCP14 association with nuclear chromatin and altering its subnuclear localization. In addition, SITCP14 overexpression enhances plant immunity to $P$. capsici, while the coexpression of the CRN12_997 effector abolishes this phenotype [74]. Accordingly, our data showed that the GmHub6 gene was upregulated in response to $M$. incognita infection but only in the resistant soybean cultivar, suggesting that its accumulation may be mainly associated with resistance improvement in the plants. Thus, we believe that the EFF1/Minc17998 effector acts by interacting with the GmHub6 protein to primarily alter the cell cycle, which in turn activates the immune system. Subsequently, the functional disturbance of the GmHub6 protein in plant cells targeted by the nematode strongly impairs the host defense responses and allows $M$. incognita to complete its life cycle. 
Given this hypothesis, the use of RNAi technology to target the Mi-EFF1/Minc17998 effector may be an interesting strategy for improving resistance to $M$. incognita in transgenic plants. This hypothesis is supported by the low genetic variability (approx. $0.02 \%$ of nucleotides) observed in protein-coding regions among different $M$. incognita races or isolates [75]. In addition, only slight variations in gene copy number and expression levels have been observed among different $M$. incognita isolates and races [76]. In contrast, the expression modulation of the GmHub6 gene (or its orthologous genes in other crops of interest) via its overexpression or targeted transcriptional modulation using the CRISPR/dCas system [77] can be evaluated (or combined with an RNAi strategy) to improve plant resistance to RKNs.

\section{Conclusion}

Several features of the M. incognita Mi-EFF1/Minc17998 effector and soybean GmHub proteins (especially the GmHub6 protein) have been highlighted, and we suggest their great importance for successful plant parasitism or plant resistance, respectively. The interaction between the Mi-

EFF1/Minc17998 effector and the soybean GmHub6 protein is suggested to be a mechanism associated with a reduction in plant resistance to nematode infection via the disruption of GmHub6 activity. The high conservation of this effector in other Meloidogyne species suggests that NBTs based on RNAi could be developed to target and downregulate this effector gene in different RKN species or races. Therefore, our findings showed that the Mi-EFF1/Minc17998 effector and the soybean GmHub6 protein are powerful targets for the development of NBTs for nematode control in crops.

\section{Methods}

\section{In silico analysis of the M. incognita Mi-EFF1/Minc17998 effector and soybean GmHub proteins}

All sequences of $M$. incognita effector genes were retrieved from BioProject ID PRJEB8714 (sample ERS1696677) [56] from the online WormBase Parasite Database version WBPS13 [78]. Pairwise identity matrices for nucleotide and amino acid sequences were generated using Sequence Demarcation Tool Version 1.2 software [79]. Phylogenetic analyses of the $M$. incognita effector sequences were performed using the Phylogeny.fr web service [80]. For these analyses, sequences were aligned with MUSCLE software [81], and the alignment was curated by the Gblocks model. Then, phylogenetic analyses were performed using the maximum likelihood method with PhyML software using approximate likelihoodratio test (aLRT) SH-like branch support and the GTR and WAG substitution models for nucleotide and amino acid sequences, respectively. Phylogenetic trees were generated and visualized with TreeDyn software, which was implemented at the same web service. Comparative genomic trees were generated from BioProject PRJEB8714 [56] by the WormBase ParaSite Database using the Ensembl Compara tools. The in silico expression levels of Mi-EFF1/Minc17998 and its paralogous gene Minc3s01563g24741 in different $M$. incognita life stages were determined using transcriptome datasets (BioProject number: PRJNA390559; [82]) retrieved from the BioSample database (NCBI). For this analysis, 15 transcriptome libraries from the $M$. incognita egg, J2, J3, J4, and female stages generated by Choi et al. [82] using the Truseq RNA Sample Prep Kit (Illumina) and mRNAs that were paired-end sequenced (2x101 bp) using 
Illumina HiSeq 2000 technology were downloaded and trimmed, and the transcripts were mapped using the genome reference retrieved from the WormBase Parasite Database (BioProject ID PRJEB8714) [83]. The gene expression profiles in different nematode life stages were normalized to transcripts per million (TPM) values.

On the other hand, the sequences and characteristics of soybean genes were retrieved from G. max Wm82.a2.v1 (BioProject: PRJNA19861) [84] via the Phytozome v.12 database [85]. Conserved domains in the gene sequences were identified using the CDD Database from NCBI [86], annotation was confirmed by the HMMER prediction server [87], and nuclear signal localization (NLS) motifs were predicted using the NLStradamus online tool [88]. The pairwise identity matrices were generated, and phylogenetic analyses were performed as described above. The interactome network of soybean and $A$. thaliana hub proteins with their interacting proteins was retrieved from the STRING database v.11 platform [89]. The organ- and tissue-specific expression of the eight GmHub genes, including the top 10 soybean proteins with which GmHub6 interacted, is presented in the heat map plot generated by the PhytoMine tool (https://phytozome.jgi.doe.gov/phytomine/begin.do) using all gene expression data in the database related to tissue- and organ-specific expression.

\section{Mi-EFF1/Minc17998 expression profile determined using RT-qPCR assays}

The Mi-EFF1/Minc17998 gene expression levels in different nematode life stages (egg, J2, J2/J3, J3/J4, and female) during plant infection were determined using tomato roots inoculated with $500 \mathrm{M}$. incognita $\mathrm{J} 2$ race 3 individuals. Total RNA was isolated using the Concert ${ }^{\mathrm{TM}}$ Plant RNA Reagent (Invitrogen, Carlsbad, CA, USA) supplemented with PVP-40. The RNA concentration was estimated using a spectrophotometer (NanoDrop 2000, Thermo Scientific, Massachusetts, USA), and RNA integrity was evaluated via $1 \%$ agarose gel electrophoresis. The RNA samples were treated with RNase-free RQ1 DNase I (Promega, Madson, Wisconsin, USA) according to the manufacturer's instructions. Then, 2 to $4 \mu \mathrm{g}$ of DNase-treated RNA was employed as a template for cDNA synthesis using Oligo-(dT) ${ }_{20}$ primers and SuperScript III RT (Life Technologies, Carlsbad, CA, USA) according to the manufacturer's instructions. The cDNA was quantified by spectrophotometry and diluted $1 / 10$ with nuclease-free water. RT-qPCR assays were performed in an Applied Biosystems 7500 Fast Real-Time PCR System (Applied Biosystems, Foster City, CA, USA) using $400 \mathrm{ng}$ of cDNA, each gene-specific primer at $0.2 \mu \mathrm{M}$ (Table S1) and GoTaq ${ }^{\circledR}$ qPCR Master Mix (Promega, Madson, Wisconsin, USA). The qPCR conditions included an initial step at $95^{\circ} \mathrm{C}$ for $10 \mathrm{~min}$, then 40 cycles of $95^{\circ} \mathrm{C}$ for $15 \mathrm{~s}$ and $60^{\circ} \mathrm{C}$ for $1 \mathrm{~min}$, followed by a final melting curve analysis. The relative expression of the Mi-EFF1/Minc17998 gene was normalized using Mi18S (GenBank accession U81578) [90] as an endogenous reference gene. Three biological replicates composed of one plant each were performed, and the cDNA samples were used in technical triplicate reactions. Primer efficiency and target-specific amplification were confirmed on the basis of a single distinct peak in the melting curve analysis. The relative expression level (fold change) was calculated using the $2^{-\Delta \mathrm{Ct}}$ or method [91].

\section{In vitro and in vivo transactivation assays for the evaluation of protein-protein interactions}

Page $10 / 31$ 
Protein-protein interaction tests were performed to evaluate the interaction of the Mi-EFF1/Minc17998 effector with eight soybean hub proteins: GmHub4 (COP9 signalosome complex subunit 5), GmHub6 (TCP family transcription factor), GmHub10 (kinesin light chain), GmHub12 (APC8/anaphase -promoting complex subunit), GmHub17 (TCP family transcription factor), GmHub42 (transcription factor UNE12related), GmHub47 (jasmonate ZIM domain-containing protein), and GmHub61 (uncharacterized conserved protein containing an emsy amine-terminus domain) (Table 1). The cDNA sequences of the soybean hub proteins were amplified from total RNA isolated from the roots of the soybean cv. Williams 82. Amplicons of the expected size were cloned into the pGEMT easy vector (Promega, Madson, Wisconsin, USA) and sequenced by Macrogen (Geumcheon-gu, Seoul, South Korea); after sequence analysis, desirable amplicons were subcloned based on the restriction sites present in the primers into the entry vector of the Gateway cloning system (pENTR11; Invitrogen). Sequence identities were confirmed by comparison with gene sequences retrieved from G. max Wm82.a2.v1 (BioProject: PRJNA19861) [84] via the Phytozome v.12 database [85]. The transfer of the cDNA clones from the entry vector to the pGADT7$A D$, pGBKT7-BD, and BiFC destination vectors was performed using the enzyme Gateway ${ }^{\mathrm{TM}}$ LR Clonase $^{\mathrm{TM}}$ II Enzyme mix (Invitrogen). The full-length cDNA sequence of the Mi-EFF1/Minc17998 effector was synthesized by Epoch Life Science (Sugar Land, TX, USA), cloned into the pENTR11 vector, propagated in E. coli $\mathrm{DH} 5 \mathrm{a}$, and subsequently transferred to the pGADT7-AD and pGBKT7-BD destination vectors using the LR clonase system. Y2H experiments were performed using the Matchmaker ${ }^{T M}$ GAL4 Two-Hybrid System 3 (Clontech) based on the GAL4 binding (BD) and transactivation (AD) domains present in these destination vectors. Both $\mathrm{Y} 2 \mathrm{H}$ vectors were sequentially cotransformed into competent cells of the Saccharomyces cerevisiae YRG2 strain (Mata, ura3-52, his3-200, ade2-101, lys2-801, trp1-901, leu2-3, 112, gal4-542, gal80-538) using the lithium acetate/polyethylene glycol (PEG) method. Single colonies of cotransformed yeast were grown overnight in selective yeast nitrogen base (YNB) medium in a shaking incubator at $180 \mathrm{rpm}$ at $30^{\circ} \mathrm{C}$. Yeast cells were diluted in fresh YNB medium to an optical dilution $\left(\mathrm{OD}_{600}\right)$ of approximately 1 to 0.01 . Then, $100 \mu$ of the suspension was plated on synthetic dropout medium lacking leucine, tryptophan, and histidine and containing the 3-amino-1,2,4-triazole (3-AT) His3 geneproduct competitive inhibitor at 5 to $10 \mathrm{mM}$, followed by incubation at $28^{\circ} \mathrm{C}$ for three to five days. The empty pGADT7-AD and pGBKT7-BD vectors were used as negative controls for protein-protein interactions, while pGADT7-AD::NIG and pGBKT7-BD::AtWWP1 were used as positive controls. The $A$. thaliana AtWWP1 (AT2G41020) and NIG (AT4G13350) protein interactions were previously validated by Calil et al. [92].

BiFC assays were carried out using different combinations of the $A$. tumefaciens GV3101 strain carrying pSITE BiFC cEFYP (GU734652) and nEYFP (GU734651) binary vectors containing the 35S:GmHub6-cYFP and 35S:Mi-EFF1/Minc17998-nYFP fusion proteins. An A. tumefaciens coculture was coinfiltrated into the abaxial surface of $N$. tabacum leaves at an $\mathrm{OD}_{600} \mathrm{~nm}$ of 0.7 at a final ratio of 1:1. Yellow fluorescence was analyzed in epidermal cells three days after infiltration using a Zeiss inverted LSM510 META laser scanning microscope equipped with an argon laser and a helium laser as excitation sources. Yellow fluorescent protein (YFP) was excited at $514 \mathrm{~nm}$ using an argon laser, and YFP emission was detected using a 560-615-nm filter.

Page $11 / 31$ 


\section{GmHub6 expression profile in soybean roots during $M$. incognita infection}

M. incognita J2 race 1 was obtained from tomato plants (Solanum lycopersicum cv. Santa Clara) that were inoculated and maintained for eight to ten weeks under greenhouse conditions. Infected roots were washed and macerated using a blender after treatment with $0.5 \%$ sodium hypochlorite. Eggs were harvested, rinsed with tap water, and subsequently separated from root debris using 100 - to $550-\mu \mathrm{m}$ sieves [93]. Then, the eggs were hatched under aerobic conditions at $28^{\circ} \mathrm{C}$, and $\mathrm{J} 2$ individuals were harvested every two days, decanted and quantified under a microscope using a counting chamber. Soybean plants were inoculated with 1,000 newly hatched $M$. incognita J2 individuals suspended in distilled water. The conventional soybean cultivars PI595099 (resistant) and BRS133 (susceptible), which are considered to exhibit contrasting RKN resistance levels [94], were inoculated with 1,000 M. incognita $\mathrm{J} 2$ individuals, and axillary root samples were harvested at 3, 8, 15, and 25 dpi from mock- and nematode-inoculated plants. Total RNA was purified using the Concert ${ }^{\text {TM }}$ Plant RNA Reagent (Invitrogen, Carlsbad, CA, USA) supplemented with PVP-40, and cDNA was synthesized from DNA-free, highly pure RNA as described above. The expression profile of the GmHub6 gene during nematode infection was measured by RT-qPCR assays using specific primers and normalized with GmCYP18 (Glyma.12G024700) as an endogenous reference gene (Table S1). The thermocycling reactions and conditions used were the same as those described above. Four biological replicates were performed for each treatment, and each biological replicate was composed of four plants. All cDNA samples were used in technical triplicates, and primer efficiency and target-specific amplification were confirmed by a single, distinct peak in the melting curve analysis. The relative expression level (fold-change) was calculated using the $2^{-\Delta \mathrm{Ct}}$ method [91].

\section{M. incognita resistance assessment of the AtHub6 mutant}

A. thaliana seeds from the AtHub6 gene mutant line hub6 (T-DNA insertion; attcp14-5, GK611C04/CS458588, of AT3G47620, an orthologous gene of soybean GmHub6; Additional file 1) and the null mutant line for the enhanced disease susceptibility 1 (eds 1; AT3G48090; SALK_034340) gene were obtained from the Arabidopsis Biological Resource Center (ABRC; Columbus OH, 43210, USA). The $A$. thaliana seeds were surfaced sterilized and sown in Murashige and Skoog (MS)-containing agar plates. The plates were stratified in the dark at $4^{\circ} \mathrm{C}$ for $72 \mathrm{~h}$. Plants were grown in a growth chamber at $22^{\circ} \mathrm{C}$ under a $12 \mathrm{~h}$ light/ $12 \mathrm{~h}$ dark photoperiod. For growth under in vivo conditions, plants from the WT, AtEds 1 , and AtHub6 lines were transferred to 1:1 substrate: sand (autoclaved commercial substrate and sand at a 1:1 ratio) and grown as described above. Then, two- or three-week-old plants were inoculated with $250 \mathrm{M}$. incognita J2 individuals as described above. The inoculated roots were harvested at 5, 10, 15, and 25 days postinoculation (dpi) and stained with acid fuchsin as described by Bybd et al. [95], and the penetration efficiency in the roots, the post penetration development of the nematodes, and the formation of galls were evaluated. In addition, the number of eggs per gram of roots, the number of $\mathrm{J} 2$ individuals per gram of roots, the number of galls per gram of roots, and NRF were determined from an additional plant set at $40 \mathrm{dpi}$. The NRF was determined as described above, and the AtEds 1 mutant line was used as 
a susceptibility control. Each $A$. thaliana line included 15 to 20 plants, which were divided into three biological replicates.

\section{Abbreviations}

RKN: root-knot nematode; Mi: Meloidogyne incognita; PAMP: pathogen-associated molecular pattern; PTI: PAMP-triggered immunity; Gm: Glycine max, EST: expressed sequence tag; At: Arabidopsis thaliana; NBT: new biotechnological tool; Mj: Meloidogyne javanica; $\mathrm{Y} 2 \mathrm{H}$ : yeast two-hybrid; BiFC: bimolecular fluorescence complementation; WT: wild-type; AtEds1: A. thaliana Enhanced disease susceptibility 1 gene.

\section{Declarations}

\section{Acknowledgments}

We are grateful to EMBRAPA, UCB, CAPES, CNPq, INCT PlantStress Biotech, and FAP-DF for financial and scientific support. RAGM is grateful to CAPES by the doctoral research fellowship, while MFB is grateful to CNPq by the postdoctoral research fellowship (PDJ 150936/2018-4). We also thank Dr. Bum-Soo Hahn for providing access to the transcriptome datasets of different $M$. incognita life stages and to Bruna Medeiros Pereira for kindly providing the initial inoculum of $M$. incognita.

\section{Authors' contributions}

MFGS was the leading researcher for all the work and provided intellectual input and financial support. MFGS, RRF, and RAGM selected the soybean proteins and nematode effector and planned the experiments. JFA, RRF, and MGS performed soybean hub gene amplification, cloning, sequencing, and gene sequence analysis. RAGM, aided by RNL and BPM, performed the protein-protein interaction assays. MFB, RAGM, and VSM produced the $M$. incognita inoculum, performed plant inoculation, and evaluated all bioassays. MFB performed the in silico analysis and evaluated gene expression levels in nematodes and soybeans. RCT performed the data mining of 15 transcriptome libraries and the differential expression profiles of the nematode effectors. MFGS, MCMS, EVSA, MELS, DF, LLPM, and FV provided intellectual input. MFB wrote the manuscript. All authors read and approved the final version.

\section{Ethics approval and consent to participate}

Not applicable

\section{Consent for publication}

Not applicable.

\section{Competing interests}


The authors declare that they have no competing interests.

\section{References}

1. Trudgill DL, Blok VC: Apomictic, polyphagous root-knot nematodes: exceptionally successful and damaging biotrophic root pathogens. Annual Review of Phytopathology 2001, 39:53-77.

2. Abad P, Gouzy J, Aury J-M, Castagnone-Sereno P, Danchin EGJ, Deleury E, Perfus-Barbeoch L, Anthouard V, Artiguenave F, Blok VC et al: Genome sequence of the metazoan plant-parasitic nematode Meloidogyne incognita. Nature Biotechnology 2008, 26:909.

3. Castagnone-Sereno P, Danchin EGJ, Perfus-Barbeoch L, Abad P: Diversity and evolution of Root-knot nematodes, genus Meloidogyne: New insights from the genomic Era. Annual Review of Phytopathology 2013, 51(1):203-220.

4. Triantaphyllou A, Hirschmann H: Post infection development of Meloidogyne incognita Chitwood 1949 (Nematoda-Heteroderidae). In: Annales de I'Institut Phytopathologique Benaki: 1960. 1-11.

5. Bernard GC, Egnin M, Bonsi C: The Impact of plant-parasitic nematodes on agriculture and methods of control. In: Nematology - Concepts, Diagnosis and Control. 2017.

6. de Almeida Engler J, Vieira P, Rodiuc N, Grossi de Sa MF, Engler G: Chapter four - The plant cell cycle machinery: usurped and modulated by plant-parasitic nematodes. In: Advances in Botanical Research. Edited by Escobar C, Fenoll C, vol. 73: Academic Press; 2015: 91-118.

7. Shukla N, Yadav R, Kaur P, Rasmussen S, Goel S, Agarwal M, Jagannath A, Gupta R, Kumar A: Transcriptome analysis of root-knot nematode (Meloidogyne incognita)-infected tomato (Solanum lycopersicum) roots reveals complex gene expression profiles and metabolic networks of both host and nematode during susceptible and resistance responses. Molecular Plant Pathology 2018, 19(3):615-633.

8. Antonino de Souza Junior JD, Pierre O, Coelho RR, Grossi-de-Sa MF, Engler G, de Almeida Engler J: Application of nuclear volume measurements to comprehend the cell cycle in root-knot nematodeinduced giant cells. Frontiers in Plant Science 2017, 8:961.

9. de Almeida Engler J, Van Poucke K, Karimi M, De Groodt R, Gheysen G, Engler G, Gheysen G: Dynamic cytoskeleton rearrangements in giant cells and syncytia of nematode-infected roots. Plant Journal 2004, 38(1):12-26.

10. de Almeida Engler J, Kyndt T, Vieira P, Van Cappelle E, Boudolf V, Sanchez V, Escobar C, De Veylder L, Engler G, Abad P et al: CCS52 and DEL1 genes are key components of the endocycle in nematodeinduced feeding sites. Plant Journal 2012, 72(2):185-198.

11. Carneiro RG, MAZZAFERA P, FERRAZ LCCB, MURAOKA T, TRIVELIN PCO: Uptake and translocation of nitrogen, phosphorus and calcium in soybean infected with Meloidogyne incognita and M. javanica. Fitopatologia Brasileira 2002, 27:141-150.

12. Melakeberhan H, Webster JM, Brooke RC, D'Auria JM, Cackette M: Effect of Meloidogyne incognita on plant nutrient concentration and its influence on the physiology of beans. Journal of Nematology 
1987, 19(3):324-330.

13. Lu P, Davis RF, Kemerait RC, van lersel MW, Scherm H: Physiological effects of Meloidogyne incognita infection on cotton genotypes with differing levels of resistance in the greenhouse. Journal of Nematology 2014, 46(4):352-359.

14. Gillet FX, Bournaud C, Antonino de Souza Junior JD, Grossi-de-Sa MF: Plant-parasitic nematodes: towards understanding molecular players in stress responses. Annals of Botany 2017, 119(5):775789.

15. Lin B, Zhuo K, Wu P, Cui R, Zhang L-H, Liao J: A novel effector protein, Mj-NULG1a, targeted to giant cell nuclei plays a role in Meloidogyne javanica parasitism. Molecular Plant-Microbe Interactions 2013, 26(1):55-66.

16. Melillo MT, Leonetti P, Leone A, Veronico P, Bleve-Zacheo T: ROS and NO production in compatible and incompatible tomato-Meloidogyne incognita interactions. European Journal of Plant Pathology 2011, 130(4):489-502.

17. Manosalva P, Manohar M, von Reuss SH, Chen S, Koch A, Kaplan F, Choe A, Micikas RJ, Wang X, Kogel K-H et al: Conserved nematode signalling molecules elicit plant defenses and pathogen resistance. Nature Communications 2015, 6:7795.

18. Holscher D, Dhakshinamoorthy S, Alexandrov T, Becker M, Bretschneider T, Buerkert A, Crecelius AC, De Waele D, Elsen A, Heckel DG et al: Phenalenone-type phytoalexins mediate resistance of banana plants (Musa spp.) to the burrowing nematode Radopholus similis. PNAS 2014, 111(1):105-110.

19. Kong L-A, Wu D-Q, Huang W-K, Peng H, Wang G-F, Cui J-K, Liu S-M, Li Z-G, Yang J, Peng D-L: Largescale identification of wheat genes resistant to cereal cyst nematode Heterodera avenae using comparative transcriptomic analysis. BMC Genomics 2015, 16(1):801.

20. Bellafiore S, Shen Z, Rosso MN, Abad P, Shih P, Briggs SP: Direct identification of the Meloidogyne incognita secretome reveals proteins with host cell reprogramming potential. PLoS Pathogens 2008 , 4(10):e1000192.

21. Shinya R, Morisaka H, Kikuchi T, Takeuchi Y, Ueda M, Futai K: Secretome Analysis of the pine wood nematode Bursaphelenchus xylophilus reveals the tangled roots of parasitism and its potential for molecular mimicry. PLoS ONE 2013, 8(6):e67377.

22. Dubreuil G, Deleury E, Magliano M, Jaouannet M, Abad P, Rosso MN: Peroxiredoxins from the plant parasitic root-knot nematode, Meloidogyne incognita, are required for successful development within the host. International Journal of Parasitology 2011, 41(3-4):385-396.

23. Basso MF, Lourenço-Tessutti IT, Mendes RAG, Pinto CEM, Bournaud C, Gillet F-X, Togawa RC, de Macedo LLP, de Almeida Engler J, Grossi-de-Sa MF: MiDaf16-like and MiSkn1-like gene families are reliable targets to develop biotechnological tools for the control and management of Meloidogyne incognita. Scientific Reports 2020, 10(1):6991.

24. Xie J, Li S, Mo C, Wang G, Xiao X, Xiao Y: A novel Meloidogyne incognita effector Misp12 suppresses plant defense response at latter stages of nematode parasitism. Frontiers in Plant Science 2016, 7:964-964. 
25. Lin B, Zhuo K, Chen S, Hu L, Sun L, Wang X, Zhang L-H, Liao J: A novel nematode effector suppresses plant immunity by activating host reactive oxygen species-scavenging system. New Phytologist 2016, 209(3):1159-1173.

26. Bournaud C, Gillet F-X, Murad AM, Bresso E, Albuquerque EVS, Grossi-de-Sa MF: Meloidogyne incognita PASSE-MURAILLE (MiPM) gene encodes a cell-penetrating protein that interacts with the CSN5 subunit of the COP9 signalosome. Frontiers in Plant Science 2018, 9(904).

27. Nguyen CN, Perfus-Barbeoch L, Quentin M, Zhao J, Magliano M, Marteu N, Da Rocha M, Nottet N, Abad P, Favery B: A root-knot nematode small glycine and cysteine-rich secreted effector, MiSGCR1, is involved in plant parasitism. New Phytologist 2018, 217(2):687-699.

28. Grossi-de-Sa M, Petitot A-S, Xavier DA, Sá MEL, Mezzalira I, Beneventi MA, Martins NF, Baimey HK, Albuquerque EVS, Grossi-de-Sa MF et al: Rice susceptibility to root-knot nematodes is enhanced by the Meloidogyne incognita MSP18 effector gene. Planta 2019, 250(4):1215-1227.

29. Shi Q, Mao Z, Zhang X, Ling J, Lin R, Zhang X, Liu R, Wang Y, Yang Y, Cheng X et al: The novel secreted Meloidogyne incognita effector MilSE6 targets the host nucleus and facilitates parasitism in Arabidopsis. Frontiers in Plant Science 2018, 9:252-252.

30. Zhao J, Li L, Liu Q, Liu P, Li S, Yang D, Chen Y, Pagnotta S, Favery B, Abad P et al: A MIF-like effector suppresses plant immunity and facilitates nematode parasitism by interacting with plant annexins. Journal of Experimental Botany 2019, 70(20):5943-5958.

31. Niu J, Liu P, Liu Q, Chen C, Guo Q, Yin J, Yang G, Jian H: Msp40 effector of root-knot nematode manipulates plant immunity to facilitate parasitism. Scientific Reports 2016, 6(1):19443.

32. Xue B, Hamamouch N, Li C, Huang G, Hussey RS, Baum TJ, Davis EL: The 8D05 parasitism gene of Meloidogyne incognita is required for successful infection of host roots. Phytopathology 2013, 103(2):175-181.

33. Leelarasamee N, Zhang L, Gleason C: The root-knot nematode effector MiPFN3 disrupts plant actin filaments and promotes parasitism. PLoS Pathogens 2018, 14(3):e1006947.

34. Rutter WB, Hewezi T, Abubucker S, Maier TR, Huang G, Mitreva M, Hussey RS, Baum TJ: Mining novel effector proteins from the esophageal gland cells of Meloidogyne incognita. Molecular Plant-Microbe Interactions 2014, 27(9):965-974.

35. Ali MA, Azeem F, Li H, Bohlmann H: Smart parasitic nematodes use multifaceted strategies to parasitize plants. Frontiers in Plant Science 2017, 8(1699).

36. Huang G, Gao B, Maier T, Allen R, Davis EL, Baum TJ, Hussey RS: A profile of putative parasitism genes expressed in the esophageal gland cells of the root-knot nematode Meloidogyne incognita. Molecular Plant-Microbe Interactions 2003, 16(5):376-381.

37. Jaouannet M, Perfus-Barbeoch L, Deleury E, Magliano M, Engler G, Vieira P, Danchin EG, Da Rocha M, Coquillard P, Abad P et al: A root-knot nematode-secreted protein is injected into giant cells and targeted to the nuclei. New Phytologist 2012, 194(4):924-931.

38. Mukhtar MS, Carvunis AR, Dreze M, Epple P, Steinbrenner J, Moore J, Tasan M, Galli M, Hao T, Nishimura MT et al: Independently evolved virulence effectors converge onto hubs in a plant immune 
system network. Science 2011, 333(6042):596-601.

39. Wessling R, Epple P, Altmann S, He Y, Yang L, Henz SR, McDonald N, Wiley K, Bader KC, Glasser C et al: Convergent targeting of a common host protein-network by pathogen effectors from three kingdoms of life. Cell host \& microbe 2014, 16(3):364-375.

40. Consortium AIM: Evidence for network evolution in an Arabidopsis interactome map. Science 2011, 333(6042):601-607.

41. Tatematsu K, Nakabayashi K, Kamiya Y, Nambara E: Transcription factor AtTCP14 regulates embryonic growth potential during seed germination in Arabidopsis thaliana. The Plant Journal 2008, 53(1):42-52.

42. Li S: The Arabidopsis thaliana TCP transcription factors: A broadening horizon beyond development. Plant signaling \& behavior 2015, 10(7):e1044192-e1044192.

43. Spears BJ, Howton TC, Gao F, Garner CM, Mukhtar MS, Gassmann W: Direct regulation of the EFRdependent immune response by Arabidopsis TCP transcription factors. Molecular Plant-Microbe Interactions 2019, 32(5):540-549.

44. Kieffer M, Master V, Waites R, Davies B: TCP14 and TCP15 affect internode length and leaf shape in Arabidopsis. The Plant Journal 2011, 68(1):147-158.

45. Resentini F, Felipo-Benavent A, Colombo L, Blázquez Miguel A, Alabadí D, Masiero S: TCP14 and TCP15 mediate the promotion of seed germination by gibberellins in Arabidopsis thaliana. Molecular Plant 2015, 8(3):482-485.

46. Peng Y, Chen L, Lu Y, Wu Y, Dumenil J, Zhu Z, Bevan MW, Li Y: The ubiquitin receptors DA1, DAR1, and DAR2 redundantly regulate endoreduplication by modulating the stability of TCP14/15 in Arabidopsis. The Plant Cell 2015, 27(3):649-662.

47. Li M, Chen H, Chen J, Chang M, Palmer IA, Gassmann W, Liu F, Fu ZQ: TCP transcription factors interact with NPR1 and contribute redundantly to systemic acquired resistance. Frontiers in Plant Science 2018, 9(1153).

48. Yang L, Teixeira PJPL, Biswas S, Finkel OM, He Y, Salas-Gonzalez I, English ME, Epple P, Mieczkowski P, Dangl JL: Pseudomonas syringae type III effector HopBB1 promotes host transcriptional repressor degradation to regulate phytohormone responses and virulence. Cell Host \& Microbe 2017, 21(2):156-168.

49. Kim SH, Son GH, Bhattacharjee S, Kim HJ, Nam JC, Nguyen PDT, Hong JC, Gassmann W: The Arabidopsis immune adaptor SRFR1 interacts with TCP transcription factors that redundantly contribute to effector-triggered immunity. The Plant Journal 2014, 78(6):978-989.

50. Hartman GL, West ED, Herman TK: Crops that feed the World 2. Soybean-worldwide production, use, and constraints caused by pathogens and pests. Food Security 2011, 3(1):5-17.

51. USDA: World agricultural production. In: United State Departament of Agriculture - Cirucular series WAP 2-2020. https://apps.fas.usda.gov/psdonline/circulars/production.pdf; May, 2020.

52. Hamawaki OT, Hamawaki RL, Nogueira APO, Glasenapp JS, Hamawaki CDL, Silva COd: Evaluation of soybean breeding lineages to new sources of root-knot nematode resistance. Ciência e 
Agrotecnologia 2019, 43.

53. Mazzetti VCG, Visintin GL, Valério IP, Camera JN, Deuner CC, Soares PLM: Reaction of soybean cultivars to Meloidogyne javanica and Meloidogyne incognita. Revista Ceres 2019, 66:220-225.

54. Basso MF, Ferreira PCG, Kobayashi AK, Harmon FG, Nepomuceno AL, Molinari HBC, Grossi-de-Sa MF: MicroRNAs and new biotechnological tools for its modulation and improving stress tolerance in plants. Plant Biotechnology Journal 2019.

55. Basso M, Arraes FBM, Grossi-de-Sa M, Moreira VJV, Alves-Ferreira M, MF G-d-S: Insights into genetic and molecular elements for transgenic crop development. Frontiers in Plant Science 2020, Ahead of print.

56. Blanc-Mathieu R, Perfus-Barbeoch L, Aury J-M, Da Rocha M, Gouzy J, Sallet E, Martin-Jimenez C, Bailly-Bechet M, Castagnone-Sereno P, Flot J-F et al: Hybridization and polyploidy enable genomic plasticity without sex in the most devastating plant-parasitic nematodes. In: PLoS Genetics vol. 13; 2017: e1006777.

57. Bao Z, Yang H, Hua J: Perturbation of cell cycle regulation triggers plant immune response via activation of disease resistance genes. PNAS 2013, 110(6):2407-2412.

58. Fan M, Bai MY, Kim JG, Wang T, Oh E, Chen L, Park CH, Son SH, Kim SK, Mudgett MB et al: The bHLH transcription factor HBI1 mediates the trade-off between growth and pathogen-associated molecular pattern-triggered immunity in Arabidopsis. The Plant Cell 2014, 26(2):828-841.

59. Eloy NB, de Freitas Lima M, Ferreira PCG, Inzé D: The role of the anaphase-promoting complex/cyclosome in plant growth. Critical Reviews in Plant Sciences 2015, 34(5):487-505.

60. Neuser J, Metzen CC, Dreyer BH, Feulner C, van Dongen JT, Schmidt RR, Schippers JHM: HBI1 mediates the trade-off between growth and immunity through its impact on apoplastic ROS homeostasis. Cell Reports 2019, 28(7):1670-1678.e1673.

61. Bao Z, Hua J: Linking the cell cycle with innate immunity in Arabidopsis. Molecular Plant 2015, 8(7):980-982.

62. Eichmann R, Schäfer P: Growth versus immunity - a redirection of the cell cycle? Current Opinion in Plant Biology 2015, 26:106-112.

63. Hou S, Liu Z, Shen H, Wu D: Damage-associated molecular pattern-triggered immunity in plants. Frontiers in Plant Science 2019, 10(646):1-16.

64. Holbein J, Grundler FMW, Siddique S: Plant basal resistance to nematodes: an update. Journal of Experimental Botany 2016, 67(7):2049-2061.

65. de Almeida Engler J, Gheysen G: Nematode-induced endoreduplication in plant host cells: why and how? Molecular Plant-Microbe Interactions 2013, 26(1):17-24.

66. Coelho RR, Vieira P, Antonino de Souza Júnior JD, Martin-Jimenez C, De Veylder L, Cazareth J, Engler G, Grossi-de-Sa MF, de Almeida Engler J: Exploiting cell cycle inhibitor genes of the KRP family to control root-knot nematode induced feeding sites in plants. Plant, Cell \& Environment 2017, 40(7):1174-1188. 
67. Cook DE, Mesarich $\mathrm{CH}$, Thomma BPHJ: Understanding plant immunity as a surveillance system to detect invasion. Annual Review of Phytopathology 2015, 53(1):541-563.

68. Silva MS, Arraes FBM, Campos MA, Grossi-de-Sa M, Fernandez D, Cândido ES, Cardoso MH, Franco OL, Grossi-de-Sa MF: Review: Potential biotechnological assets related to plant immunity modulation applicable in engineering disease-resistant crops. Plant Science 2018, 270:72-84.

69. Mejias J, Truong NM, Abad P, Favery B, Quentin M: Plant proteins and processes targeted by parasitic nematode effectors. Frontiers in Plant Science 2019, 10(970).

70. Quentin M, Abad P, Favery B: Plant parasitic nematode effectors target host defense and nuclear functions to establish feeding cells. Frontiers in Plant Science 2013, 4(53).

71. Goverse A, Smant G: The activation and suppression of plant innate immunity by parasitic nematodes. Annual Review of Phytopathology 2014, 52(1):243-265.

72. Hamamouch N, Li C, Hewezi T, Baum TJ, Mitchum MG, Hussey RS, Vodkin LO, Davis EL: The interaction of the novel $30 \mathrm{CO} 2$ cyst nematode effector protein with a plant beta-1,3-endoglucanase may suppress host defence to promote parasitism. Journal of Experimental Botany 2012, 63(10):3683-3695.

73. Davies LJ, Zhang L, Elling AA: The Arabidopsis thaliana papain-like cysteine protease RD21 interacts with a root-knot nematode effector protein. Nematology 2015, 17(6):655-666.

74. Stam R, Motion GB, Boevink PC, Huitema E: A conserved oomycete CRN effector targets and modulates tomato TCP14-2 to enhance virulence. BioRxiv 2013:001248.

75. Koutsovoulos GD, Marques E, Arguel M-J, Duret L, Machado ACZ, Carneiro RMDG, Kozlowski DK, Bailly-Bechet M, Castagnone-Sereno P, Albuquerque EVS et al: Population genomics supports clonal reproduction and multiple independent gains and losses of parasitic abilities in the most devastating nematode pest. Evolutionary Applications 2020, n/a(n/a):1-16.

76. Castagnone-Sereno P, Mulet K, Danchin EGJ, Koutsovoulos GD, Karaulic M, Da Rocha M, BaillyBechet M, Pratx L, Perfus-Barbeoch L, Abad P: Gene copy number variations as signatures of adaptive evolution in the parthenogenetic, plant-parasitic nematode Meloidogyne incognita. Molecular ecology 2019, 28(10):2559-2572.

77. Roca Paixão JF, Gillet F-X, Ribeiro TP, Bournaud C, Lourenço-Tessutti IT, Noriega DD, Melo BPd, de Almeida-Engler J, Grossi-de-Sa MF: Improved drought stress tolerance in Arabidopsis by CRISPR/dCas9 fusion with a Histone AcetylTransferase. Scientific Reports 2019, 9(1):8080.

78. Lee RY N, Howe KL, Harris TW, Arnaboldi V, Cain S, Chan J, Chen WJ, Davis P, Gao S, Grove C et al: WormBase 2017: molting into a new stage. Nucleic Acids Research 2017, 46(D1):D869-D874.

79. Muhire BM, Varsani A, Martin DP: SDT: a virus classification tool based on pairwise sequence alignment and identity calculation. PloS ONE 2014, 9(9):e108277-e108277.

80. Dereeper A, Guignon V, Blanc G, Audic S, Buffet S, Chevenet F, Dufayard JF, Guindon S, Lefort V, Lescot $\mathrm{M}$ et al: Phylogeny.fr: robust phylogenetic analysis for the non-specialist. Nucleic Acids Research 2008, 36(Web Server issue):W465-469. 
81. Edgar RC: MUSCLE: multiple sequence alignment with high accuracy and high throughput. Nucleic Acids Research 2004, 32(5):1792-1797.

82. Choi I, Subramanian P, Shim D, Oh B-J, Hahn B-S: RNA-seq of plant-parasitic nematode Meloidogyne incognita at various stages of its development. Frontiers in Genetics 2017, 8:190-190.

83. Szitenberg A, Salazar-Jaramillo L, Blok VC, Laetsch DR, Joseph S, Williamson VM, Blaxter ML, Lunt DH: Comparative genomics of apomictic root-knot nematodes: hybridization, ploidy, and dynamic genome change. Genome Biology and Evolution 2017, 9(10):2844-2861.

84. Schmutz J, Cannon SB, Schlueter J, Ma J, Mitros T, Nelson W, Hyten DL, Song Q, Thelen JJ, Cheng J et al: Genome sequence of the palaeopolyploid soybean. Nature 2010, 463(7278):178-183.

85. Goodstein DM, Shu S, Howson R, Neupane R, Hayes RD, Fazo J, Mitros T, Dirks W, Hellsten U, Putnam $\mathrm{N}$ et al: Phytozome: a comparative platform for green plant genomics. Nucleic Acids Research 2012, 40(Database issue):D1178-D1186.

86. Marchler-Bauer A, Derbyshire MK, Gonzales NR, Lu S, Chitsaz F, Geer LY, Geer RC, He J, Gwadz M, Hurwitz DI et al: CDD: NCBI's conserved domain database. Nucleic Acids Research 2015, 43(Database issue):D222-226.

87. Wheeler TJ, Eddy SR: NHMMER: DNA homology search with profile HMMs. Bioinformatics (Oxford, England) 2013, 29(19):2487-2489.

88. Nguyen Ba AN, Pogoutse A, Provart N, Moses AM: NLStradamus: a simple Hidden Markov Model for nuclear localization signal prediction. BMC Bioinformatics 2009, 10:202.

89. Szklarczyk D, Gable AL, Lyon D, Junge A, Wyder S, Huerta-Cepas J, Simonovic M, Doncheva NT, Morris JH, Bork P et al: STRING v11: protein-protein association networks with increased coverage, supporting functional discovery in genome-wide experimental datasets. Nucleic Acids Research 2019, 47(D1):D607-D613.

90. Dubreuil G, Magliano M, Dubrana MP, Lozano J, Lecomte P, Favery B, Abad P, Rosso MN: Tobacco rattle virus mediates gene silencing in a plant parasitic root-knot nematode. Journal Experimental Botany 2009, 60(14):4041-4050.

91. Schmittgen TD, Livak KJ: Analyzing real-time PCR data by the comparative CT method. Nature Protocols 2008, 3:1101.

92. Calil IP, Quadros IPS, Araújo TC, Duarte CEM, Gouveia-Mageste BC, Silva JCF, Brustolini OJB, Teixeira RM, Oliveira CN, Milagres RWMM et al: A WW domain-containing protein forms immune nuclear bodies against begomoviruses. Molecular Plant 2018, 11(12):1449-1465.

93. Hussey RS, Barker KR: A comparison of methods of collecting inocula of Meloidogyne spp., including a new technique. Plant Disease Reports 1973, 57:1025-1028.

94. Beneventi MA, da Silva OB, Jr., de Sá MEL, Firmino AAP, de Amorim RMS, Albuquerque EVS, da Silva MCM, da Silva JP, Campos MdA, Lopes MJC et al: Transcription profile of soybean-root-knot nematode interaction reveals a key role of phythormones in the resistance reaction. BMC Genomics $2013,14: 322-322$. 
95. Bybd DW, Kirkpatrick T, Barker KR: An improved technique for clearing and staining plant tissues for detection of nematodes. Journal of Nematology 1983, 15(1):142-143.

\section{Tables}

Table 1. Features of the eight soybean GmHub proteins retrieved from the G. max Wm82.a2.v1 (BioProject: PRJNA19861) genome dataset [84] from the Phytozome v.12 database [85]. 


\begin{tabular}{|c|c|c|c|c|c|c|c|c|c|c|}
\hline $\begin{array}{l}\text { Soyb } \\
\text { ean } \\
\text { GmH } \\
\text { ubs }\end{array}$ & $\begin{array}{l}\text { Gene } \\
\text { ID }\end{array}$ & $\begin{array}{l}\text { Gene } \\
\text { functi } \\
\text { on } \\
\text { annot } \\
\text { ation } \\
\text { s }\end{array}$ & TAIR & $\begin{array}{l}\text { Gene/ } \\
\text { CDS } \\
\text { lengt } \\
h\end{array}$ & Chr & $\begin{array}{l}\text { Chro } \\
\text { moso } \\
\text { me } \\
\text { locati } \\
\text { on } \\
\text { (STAR } \\
\text { T/EN } \\
\text { D) }\end{array}$ & $\begin{array}{l}\text { Protei } \\
\mathrm{n} \\
\mathrm{aa} / \mathrm{kD} \\
\mathrm{a}\end{array}$ & $\begin{array}{l}\text { CDD } \\
\text { doma } \\
\text { in } \\
\text { searc } \\
h\end{array}$ & $\begin{array}{l}\text { HMM } \\
\text { ER } \\
\text { predic } \\
\text { tion }\end{array}$ & $\begin{array}{l}\text { NLS } \\
\text { motif }\end{array}$ \\
\hline $\begin{array}{l}\mathrm{GmH} \\
\text { ub4 }\end{array}$ & $\begin{array}{l}\text { Glym } \\
\text { a.06G } \\
0760 \\
00\end{array}$ & $\begin{array}{l}\text { COP9 } \\
\text { signal } \\
\text { osom } \\
\text { e } \\
\text { comp } \\
\text { lex } \\
\text { subu } \\
\text { nit 5, } \\
\text { CSN5 }\end{array}$ & $\begin{array}{l}\text { AT1G } \\
2292 \\
0\end{array}$ & $\begin{array}{l}4154 / \\
1230\end{array}$ & 06 & $\begin{array}{l}5880 \\
948 / 5 \\
8851 \\
01\end{array}$ & $\begin{array}{l}409 / 4 \\
5.9\end{array}$ & $\begin{array}{l}\mathrm{cd} 080 \\
69\end{array}$ & $\begin{array}{l}\text { PF01 } \\
398.2 \\
1 \\
\text { PF18 } \\
323.1\end{array}$ & no \\
\hline $\begin{array}{l}\text { GmH } \\
\text { ub6 }\end{array}$ & $\begin{array}{l}\text { Glym } \\
\text { a.17G } \\
0991 \\
00\end{array}$ & $\begin{array}{l}\text { TCP } \\
\text { famil } \\
\text { y } \\
\text { trans } \\
\text { cripti } \\
\text { on } \\
\text { factor }\end{array}$ & $\begin{array}{l}\text { AT3G } \\
4762 \\
0\end{array}$ & $\begin{array}{l}3003 / \\
1242\end{array}$ & 17 & $\begin{array}{l}7811 \\
940 / 7 \\
8149 \\
42\end{array}$ & $\begin{array}{l}413 / 4 \\
4.8\end{array}$ & $\begin{array}{l}\text { pfam } \\
0363 \\
4\end{array}$ & $\begin{array}{l}\text { PF03 } \\
634.1 \\
3\end{array}$ & yes \\
\hline $\begin{array}{l}\text { GmH } \\
\text { ub10 }\end{array}$ & $\begin{array}{l}\text { Glym } \\
\text { a.19G } \\
0082 \\
00\end{array}$ & $\begin{array}{l}\text { Kinesi } \\
\mathrm{n} \\
\text { light } \\
\text { chain }\end{array}$ & $\begin{array}{l}\text { AT3G } \\
2796 \\
0\end{array}$ & $\begin{array}{l}3623 / \\
2103\end{array}$ & 19 & $\begin{array}{l}8106 \\
94 / 81 \\
4316\end{array}$ & $\begin{array}{l}700 / 7 \\
7.07\end{array}$ & $\begin{array}{l}\text { pfam } \\
1342 \\
4\end{array}$ & $\begin{array}{l}\text { PF13 } \\
424.6 \\
\text { PF13 } \\
176.6\end{array}$ & yes \\
\hline $\begin{array}{l}\mathrm{GmH} \\
\text { ub12 }\end{array}$ & $\begin{array}{l}\text { Glym } \\
\text { a. } 11 \mathrm{G} \\
0264 \\
00\end{array}$ & $\begin{array}{l}\text { APC8 } \\
\text { /Ana } \\
\text { phase } \\
\text { prom } \\
\text { oting } \\
\text { comp } \\
\text { lex } \\
\text { subu } \\
\text { nit }\end{array}$ & $\begin{array}{l}\text { AT3G } \\
4815 \\
0\end{array}$ & $\begin{array}{l}3708 / \\
1734\end{array}$ & 11 & $\begin{array}{l}1877 \\
873 / 1 \\
8815 \\
80\end{array}$ & $\begin{array}{l}577 / 6 \\
7.1\end{array}$ & $\begin{array}{l}\text { pfam } \\
0404 \\
9 \\
\\
\text { cl371 } \\
87\end{array}$ & $\begin{array}{l}\text { PF04 } \\
049.1 \\
3 \\
\text { PF13 } \\
181.6 \\
\text { PF13 } \\
414.6 \\
\text { PF13 } \\
176.6\end{array}$ & no \\
\hline $\begin{array}{l}\mathrm{GmH} \\
\text { ub17 }\end{array}$ & $\begin{array}{l}\text { Glym } \\
\text { a.02G } \\
1059 \\
00\end{array}$ & $\begin{array}{l}\text { TCP } \\
\text { famil } \\
\text { y } \\
\text { trans } \\
\text { cripti } \\
\text { on } \\
\text { factor }\end{array}$ & $\begin{array}{l}\text { AT1G } \\
6969 \\
0\end{array}$ & $\begin{array}{l}2169 / \\
1275\end{array}$ & 02 & $\begin{array}{l}1009 \\
0282 / \\
1009 \\
2450\end{array}$ & $\begin{array}{l}424 / 4 \\
4.1\end{array}$ & $\begin{array}{l}\text { pfam } \\
0363 \\
4\end{array}$ & $\begin{array}{l}\text { PF03 } \\
634.1 \\
3\end{array}$ & yes \\
\hline $\begin{array}{l}\mathrm{GmH} \\
\text { ub42 }\end{array}$ & $\begin{array}{l}\text { Glym } \\
\text { a.19G } \\
1609 \\
00\end{array}$ & $\begin{array}{l}\text { Trans } \\
\text { cripti } \\
\text { on } \\
\text { factor } \\
\text { UNE1 }\end{array}$ & $\begin{array}{l}\text { AT4G } \\
0259 \\
0\end{array}$ & $\begin{array}{l}4204 / \\
879\end{array}$ & 19 & $\begin{array}{l}4216 \\
0254 / \\
4216 \\
4457\end{array}$ & $\begin{array}{l}292 / 3 \\
1.2\end{array}$ & $\begin{array}{l}\text { cd189 } \\
19\end{array}$ & $\begin{array}{l}\text { PF00 } \\
010.2 \\
6\end{array}$ & yes \\
\hline
\end{tabular}


2-

Relat

ed

\begin{tabular}{|c|c|c|c|c|c|c|c|c|c|c|}
\hline $\begin{array}{l}\mathrm{GmH} \\
\mathrm{ub} 47\end{array}$ & $\begin{array}{l}\text { Glym } \\
\text { a.09G } \\
1742 \\
00\end{array}$ & $\begin{array}{l}\text { Jasm } \\
\text { onate } \\
\text { ZIM } \\
\text { doma } \\
\text { in- } \\
\text { conta } \\
\text { ining } \\
\text { protei } \\
\text { n }\end{array}$ & $\begin{array}{l}\text { AT3G } \\
1786 \\
0\end{array}$ & $\begin{array}{l}6521 / \\
1161\end{array}$ & 09 & $\begin{array}{l}3988 \\
3774 / \\
3989 \\
0294\end{array}$ & $\begin{array}{l}386 / 4 \\
1.5\end{array}$ & $\begin{array}{l}\text { pfam } \\
0620 \\
0 \\
\text { pfam } \\
0942 \\
5\end{array}$ & $\begin{array}{l}\text { PF06 } \\
200.1 \\
4 \\
\text { PF09 } \\
425.1 \\
0\end{array}$ & no \\
\hline $\begin{array}{l}\mathrm{GmH} \\
\mathrm{ub61}\end{array}$ & $\begin{array}{l}\text { Glym } \\
\text { a.02G } \\
1788 \\
00\end{array}$ & $\begin{array}{l}\text { Unch } \\
\text { aract } \\
\text { erized } \\
\text { conse } \\
\text { rved } \\
\text { protei } \\
\text { n } \\
\text { conta } \\
\text { ining } \\
\text { an } \\
\text { emsy } \\
\text { amin } \\
\text { e- } \\
\text { termi } \\
\text { nus } \\
\text { doma } \\
\text { in }\end{array}$ & $\begin{array}{l}\text { AT5G } \\
0678 \\
0\end{array}$ & $\begin{array}{l}7710 / \\
1275\end{array}$ & 02 & $\begin{array}{l}3028 \\
2810 / \\
3029 \\
0519\end{array}$ & $\begin{array}{l}424 / 4 \\
7.4\end{array}$ & $\begin{array}{l}\text { pfam } \\
0373 \\
5 \\
\text { smart } \\
0074 \\
3\end{array}$ & $\begin{array}{l}\text { PF03 } \\
735.1 \\
4\end{array}$ & no \\
\hline
\end{tabular}

Chr: chromosome; aa: amino acid.

Table 2. Features of the soybean GmHub6 (Glyma.17G099100) gene and its interactor genes retrieved from the G. max Wm82.a2.v1 (BioProject: PRJNA19861) genome dataset [84] from the Phytozome v.12 database [85]. 


\begin{tabular}{|c|c|c|c|c|c|c|c|c|}
\hline Gene ID & $\begin{array}{l}\text { Gene } \\
\text { functio } \\
\text { n } \\
\text { annotat } \\
\text { ions }\end{array}$ & $\begin{array}{l}\text { Gene } \\
\text { length }\end{array}$ & $\begin{array}{l}\text { Chromo } \\
\text { some }\end{array}$ & $\begin{array}{l}\text { Chromo } \\
\text { some } \\
\text { location } \\
\text { (START } \\
\text { ) }\end{array}$ & $\begin{array}{l}\text { Chromo } \\
\text { some } \\
\text { location } \\
\text { (END) }\end{array}$ & $\begin{array}{l}\text { CDD } \\
\text { domain } \\
\text { search }\end{array}$ & $\begin{array}{l}\text { HMMER } \\
\text { predicti } \\
\text { on }\end{array}$ & $\begin{array}{l}\text { NLS } \\
\text { motif }\end{array}$ \\
\hline $\begin{array}{l}\text { Glyma. } \\
17 \text { G099 } \\
100\end{array}$ & $\begin{array}{l}\text { TCP } \\
\text { family } \\
\text { transcri } \\
\text { ption } \\
\text { factor }\end{array}$ & 3003 & Chr17 & $\begin{array}{l}781194 \\
0\end{array}$ & $\begin{array}{l}781494 \\
2\end{array}$ & $\begin{array}{l}\text { pfam03 } \\
634\end{array}$ & $\begin{array}{l}\text { PF0363 } \\
4\end{array}$ & yes \\
\hline $\begin{array}{l}\text { Glyma. } \\
01 \mathrm{G} 014 \\
900\end{array}$ & $\begin{array}{l}\text { Inactive } \\
\text { shikima } \\
\text { te } \\
\text { kinase } \\
\text { like 2, } \\
\text { alpha- } \\
\text { crystalli } \\
\text { n } \\
\text { domain } \\
\text { (ACD) }\end{array}$ & 4301 & Chr01 & $\begin{array}{l}147998 \\
6\end{array}$ & $\begin{array}{l}148428 \\
6\end{array}$ & $\begin{array}{l}\text { cl00175 } \\
\text { and } \\
\text { cl31839 }\end{array}$ & $\begin{array}{l}\text { PF0120 } \\
2\end{array}$ & no \\
\hline $\begin{array}{l}\text { Glyma. } \\
04 G 094 \\
000\end{array}$ & $\begin{array}{l}\text { Chaper } \\
\text { one } \\
\text { DNAJ- } \\
\text { domain } \\
\text { containi } \\
\text { ng } \\
\text { protein }\end{array}$ & 1396 & ChrO4 & $\begin{array}{l}835919 \\
3\end{array}$ & $\begin{array}{l}836058 \\
8\end{array}$ & $\begin{array}{l}\text { pfam00 } \\
226\end{array}$ & $\begin{array}{l}\text { PF0022 } \\
6\end{array}$ & yes \\
\hline $\begin{array}{l}\text { Glyma. } \\
07 \mathrm{G} 143 \\
100\end{array}$ & $\begin{array}{l}\text { Chaper } \\
\text { one } \\
\text { protein } \\
\text { DNAJ- } \\
\text { like } \\
\text { protein }\end{array}$ & 4672 & Chr07 & $\begin{array}{l}170469 \\
32\end{array}$ & $\begin{array}{l}170516 \\
03\end{array}$ & cl31697 & no & no \\
\hline $\begin{array}{l}\text { Glyma. } \\
10 \mathrm{G} 240 \\
200\end{array}$ & $\begin{array}{l}\text { Transcri } \\
\text { ption } \\
\text { factor } \\
\text { TCP9 }\end{array}$ & 1075 & Chr10 & $\begin{array}{l}468716 \\
73\end{array}$ & $\begin{array}{l}468727 \\
47\end{array}$ & cl23822 & $\begin{array}{l}\text { PF0363 } \\
4\end{array}$ & yes \\
\hline $\begin{array}{l}\text { Glyma. } \\
\text { 12G168 } \\
300\end{array}$ & $\begin{array}{l}\text { TCP } \\
\text { family } \\
\text { transcri } \\
\text { ption } \\
\text { factor }\end{array}$ & 2777 & Chr12 & $\begin{array}{l}323204 \\
19\end{array}$ & $\begin{array}{l}323231 \\
95\end{array}$ & $\begin{array}{l}\text { pfam03 } \\
634\end{array}$ & $\begin{array}{l}\text { PF0363 } \\
4\end{array}$ & yes \\
\hline $\begin{array}{l}\text { Glyma. } \\
14 \mathrm{G} 021 \\
600\end{array}$ & $\begin{array}{l}\text { Helicas } \\
\text { e- } \\
\text { related } \\
\text { // } \\
\text { subfam } \\
\text { ily not } \\
\text { named }\end{array}$ & 2041 & Chr14 & $\begin{array}{l}152827 \\
3\end{array}$ & $\begin{array}{l}153031 \\
3\end{array}$ & $\begin{array}{l}\text { COG057 } \\
1 \text { and } \\
\text { cd0004 } \\
8\end{array}$ & $\begin{array}{l}\text { PF0003 } \\
5 \text { and } \\
\text { PF0063 } \\
6\end{array}$ & no \\
\hline \multirow[t]{2}{*}{$\begin{array}{l}\text { Glyma. } \\
\text { 16G004 }\end{array}$} & $\begin{array}{l}\text { TCP } \\
\text { family }\end{array}$ & 1908 & Chr16 & 237659 & 239566 & $\begin{array}{l}\text { pfam03 } \\
634\end{array}$ & $\begin{array}{l}\text { PF0363 } \\
4\end{array}$ & no \\
\hline & & & & Page $24 / 31$ & & & & \\
\hline
\end{tabular}




\begin{tabular}{|c|c|c|c|c|c|c|c|c|}
\hline 300 & $\begin{array}{l}\text { transcri } \\
\text { ption } \\
\text { factor }\end{array}$ & & & & & & & \\
\hline $\begin{array}{l}\text { Glyma. } \\
18 G 296 \\
100\end{array}$ & $\begin{array}{l}\text { Small } \\
\text { nuclear } \\
\text { ribonucl } \\
\text { eoprotei } \\
\text { n } 35 \\
\text { kDa } \\
\text { protein }\end{array}$ & 4256 & Chr18 & $\begin{array}{l}573146 \\
63\end{array}$ & $\begin{array}{l}573189 \\
18\end{array}$ & $\begin{array}{l}\text { cd1223 } \\
7 \text { and } \\
\text { cl36939 }\end{array}$ & $\begin{array}{l}\text { PF0007 } \\
6\end{array}$ & yes \\
\hline $\begin{array}{l}\text { Glyma. } \\
20 \mathrm{G} 154 \\
400\end{array}$ & $\begin{array}{l}\text { Transcri } \\
\text { ption } \\
\text { factor } \\
\text { TCP9 }\end{array}$ & 1833 & Chr20 & $\begin{array}{l}393409 \\
12\end{array}$ & $\begin{array}{l}393427 \\
44\end{array}$ & cl23822 & $\begin{array}{l}\text { PF0363 } \\
4\end{array}$ & yes \\
\hline $\begin{array}{l}\text { Glyma. } \\
\text { 20G189 } \\
400\end{array}$ & $\begin{array}{l}\text { Signal- } \\
\text { recognit } \\
\text { ion- } \\
\text { particle } \\
\text { GTPase }\end{array}$ & 369 & Chr20 & $\begin{array}{l}427913 \\
57\end{array}$ & $\begin{array}{l}427917 \\
25\end{array}$ & cl28914 & no & no \\
\hline
\end{tabular}

\section{Figures}


A) Nucleotide sequences

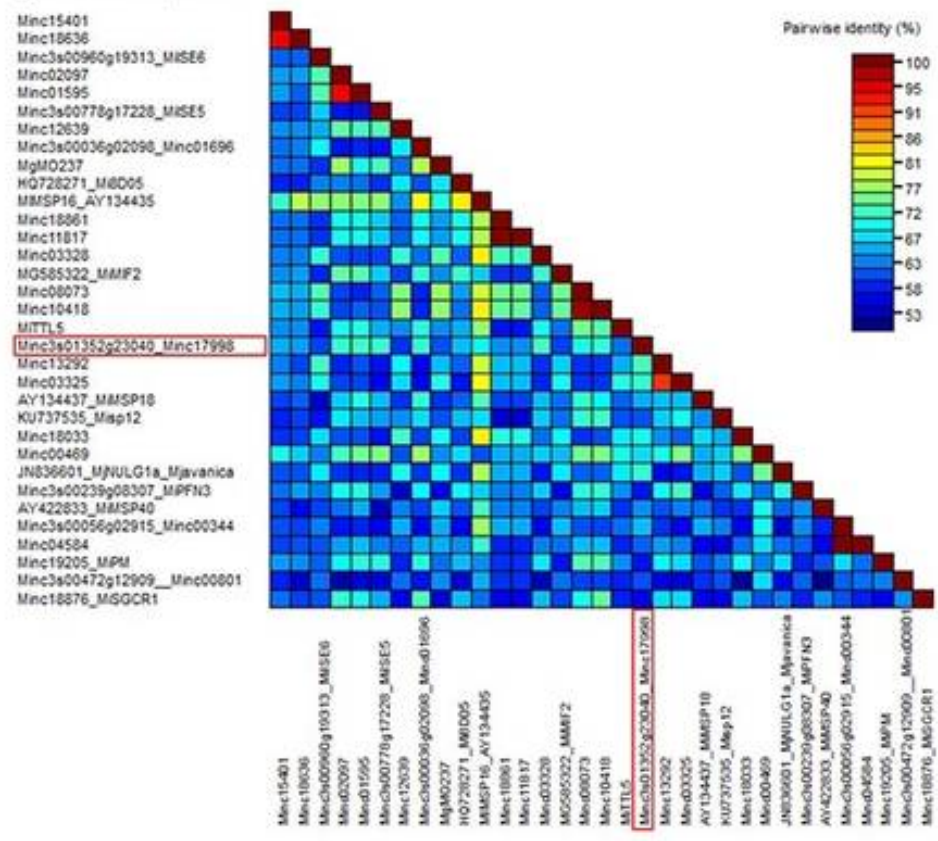

C) Nucleotide sequences

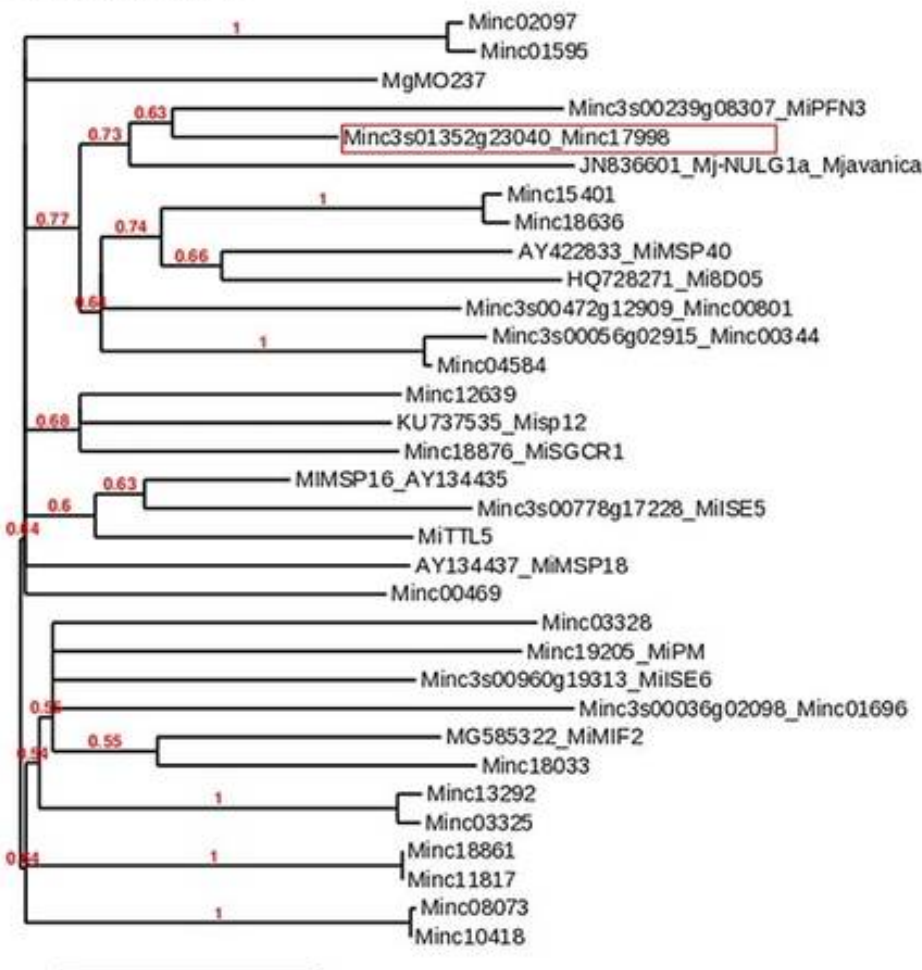

0.7

E)
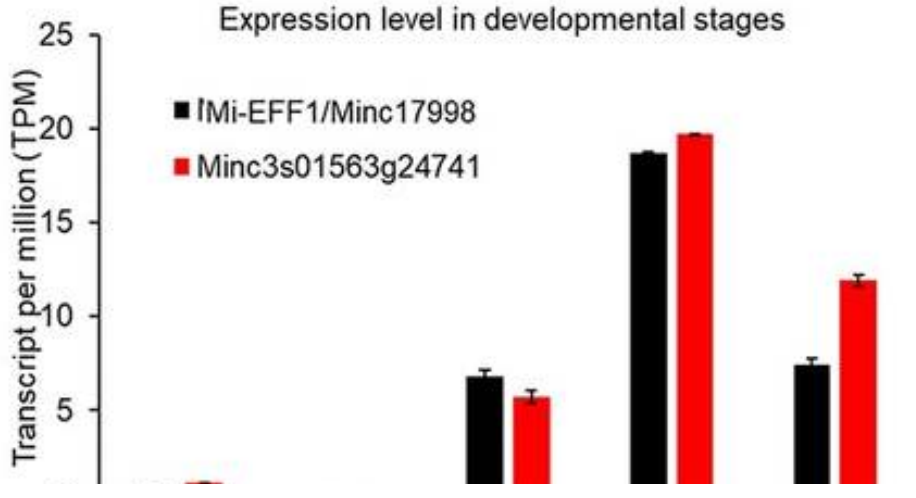

B) Amino acid sequences

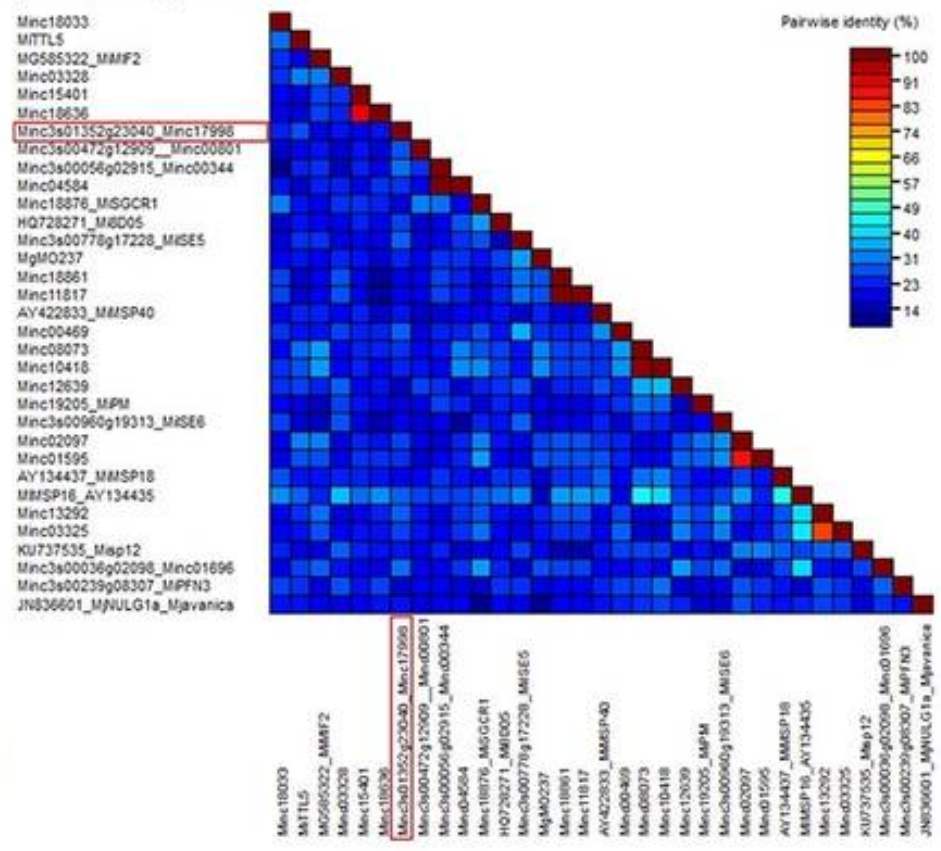

D) Amino acid sequences

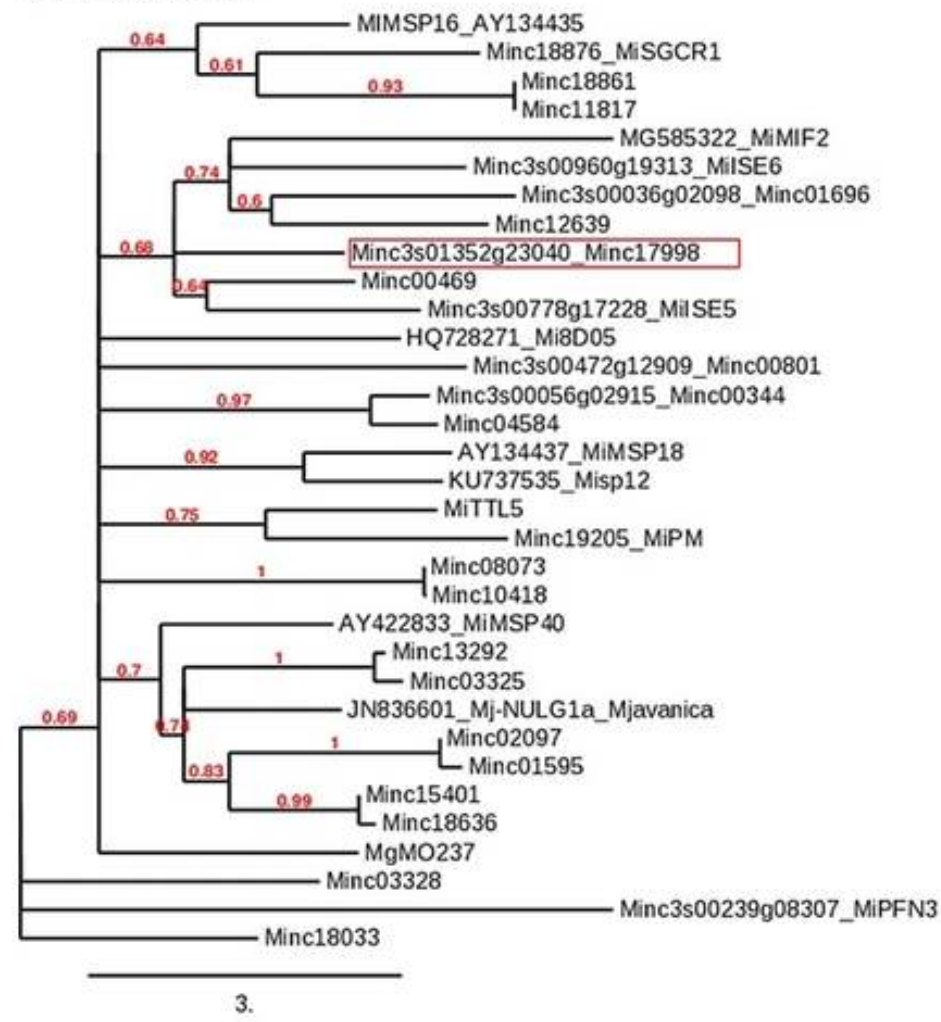

F)

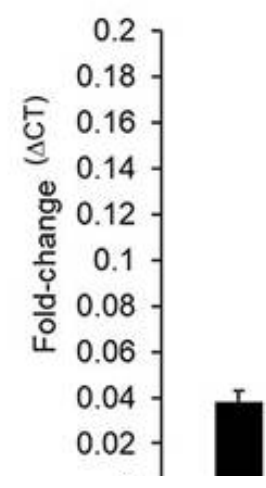

Mi-EFF1/Minc17998 expression level

Page 26/31 
0

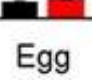

$\mathrm{J} 2$

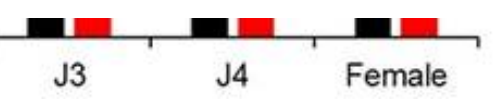

$0+$

Egg

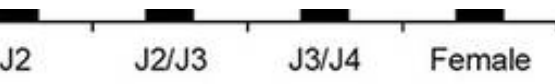

\section{Figure 1}

Sequence analysis and expression profile of the Mi-EFF1/Minc17998 effector. Pairwise sequence identity matrices of $(A)$ nucleotide and $(B)$ amino acid sequences generated using Sequence Demarcation Tool version 1.2 software [79]. Evolutionary analysis of (C) nucleotide and (D) amino acid sequences generated by the Phylogeny.fr web service [80]. Gene sequences were retrieved from the online WormBase Parasite Database version WBPS13 [78]. (E) Expression profile of the nematode Mi-EFF1/Minc17998 effector and its paralogous gene Minc3s01563g24741 in different life stages (egg, J2, J3, J4, and female) of $M$. incognita determined using transcriptome datasets (BioProject number: PRJNA390559; [82]) retrieved from the BioSample database (NCBI). Error bars represent confidence intervals corresponding to three libraries per life stage of the nematode. (F) Expression profile measured by realtime RT-qPCR of the Mi-EFF1/Minc17998 effector in different life stages of M. incognita race 3 during tomato parasitism. The fold-change values were calculated with the 2- $\Delta \mathrm{CT}$ formula using the Mi18S gene as the endogenous reference gene (Table S1). Error bars represent the confidence intervals corresponding to three biological replicates. 
A) $\underline{\mathrm{Y} 2 \mathrm{H}}$

\begin{tabular}{l}
\multicolumn{2}{r}{ Mi-EFF1 } \\
GmHub4 - \\
GmHub6 + \\
GmHub10 - \\
GmHub12 - \\
GmHub17 - \\
GmHub42 - \\
GmHub47 - \\
GmHub61 -
\end{tabular}

B) $\quad \mathrm{OD}$
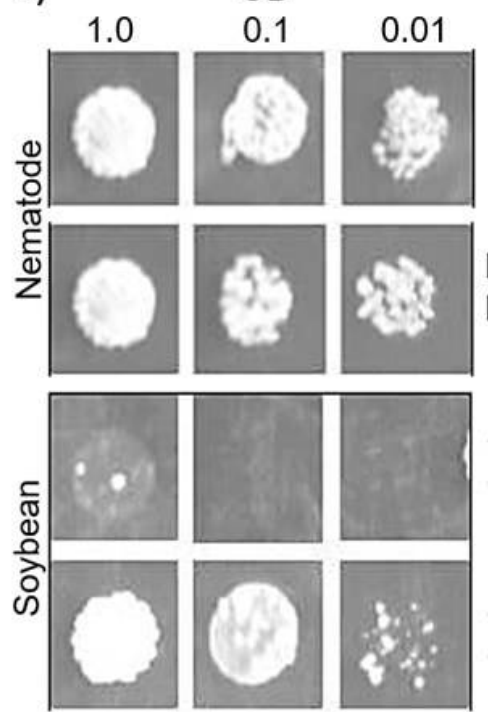

SD/-leu/-trip/-his +10 mM 3-AT
C)

Mi-EFF1-AD

Mi-EFF1-BD

Mi-EFF1-BD Mi-EFF1-AD

GmHub6-AD GmHub6-BD

GmHub6-BD GmHub6-AD

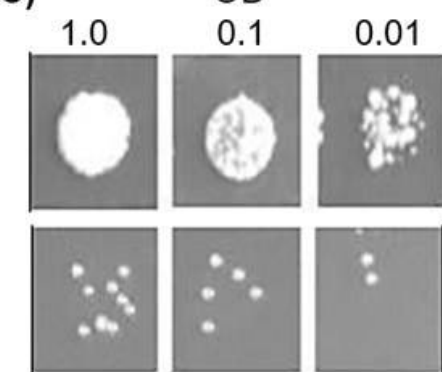

Mi-EFF1-BD GmHub6-AD 5 mM 3-AT

Mi-EFF1-BD GmHub6-AD $10 \mathrm{mM}$ 3-AT

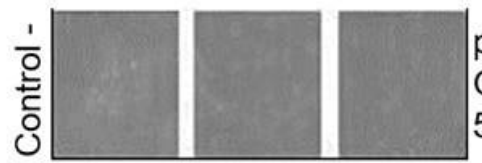

pGBK empty-BD GmHub6-AD 5 mM 3-AT

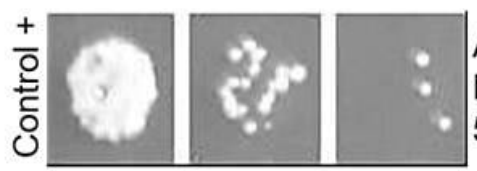

AtWWP1-BD NIG-AD $5 \mathrm{mM}$ 3-AT

D)
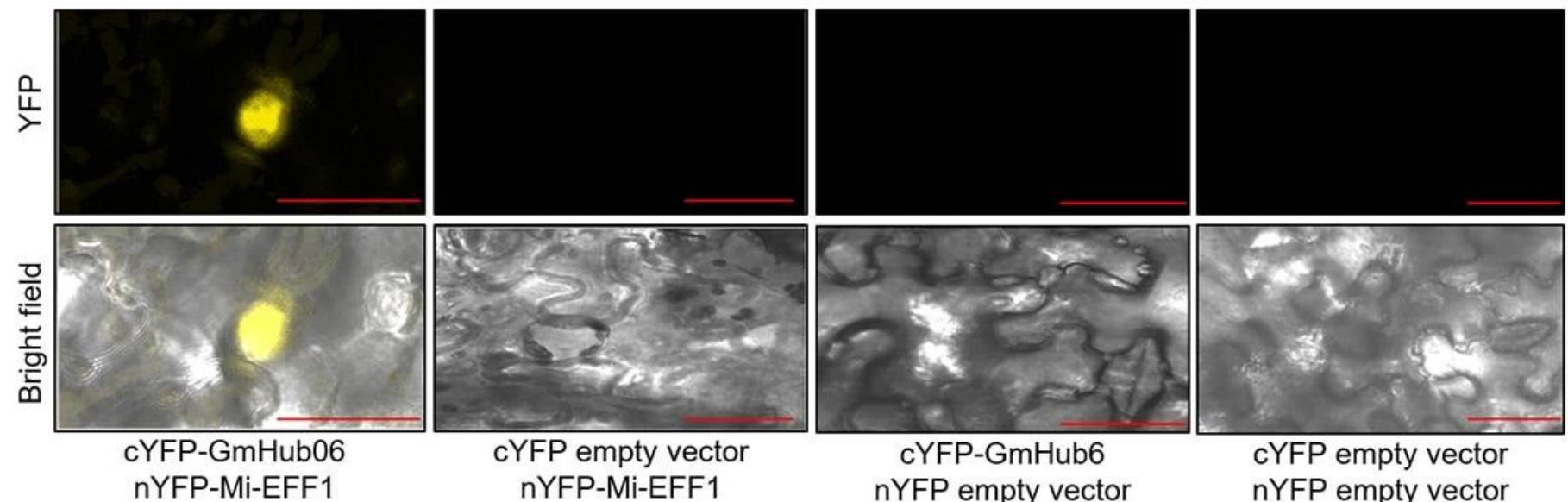

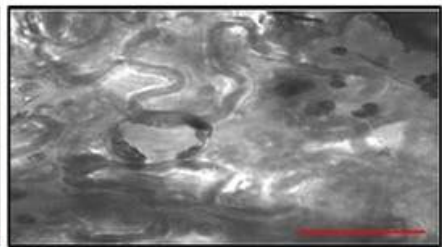

cYFP empty vector nYFP-Mi-EFF1

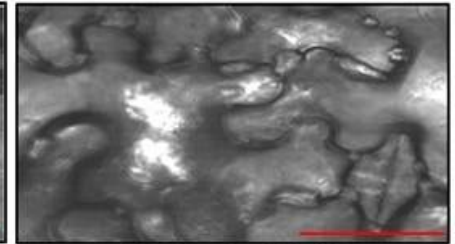

cYFP-GmHub6 nYFP empty vector

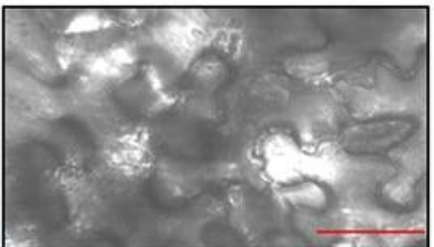

cYFP empty vector nYFP empty vector

\section{Figure 2}

Protein-protein interaction assays between the Mi-EFF1/Minc17998 effector and eight soybean GmHub proteins. (A) Yeast two-hybrid (Y2H) results for the Mi-EFF1/Minc17998 effector and the soybean GmHub4 (Glyma.06G076000), GmHub6 (Glyma.17G099100), GmHub10 (Glyma.19G008200), GmHub12 (Glyma.11G026400), GmHub17 (Glyma.02G105900), GmHub42 (Glyma.19G160900), GmHub47 (Glyma.09G174200), and GmHub61 (Glyma.02G178800) proteins (Table 1). Mi-EFF1/Minc17998 and the soybean GmHub proteins were expressed in yeast with a GAL4 activation domain (AD) and binding domain (BD) fusions. The interactions between these proteins were examined by monitoring histidine prototrophy. Yeast cells were transformed with a combination of DNA constructs, and proteins were expressed in yeast and assayed for interaction on selective synthetic medium (SD) in the presence of 5 to 10 mM 3-amino-1,2,4-triazol (3-AT) and cell dilutions at an optical density (OD) of 1.0, 0.1 or 0.01. (B) Autoactivation assays with Mi-EFF1/Minc17998 and GmHub6 proteins. (C) Mi-EFF1/Minc17998 and GmHub6 protein interactions in $\mathrm{Y} 2 \mathrm{H}$ screening. The protein-protein interactions were evaluated using pGBK empty vector-BD + GmHub6-AD and AtWWP1 (AT2G41020)-BD + NIG (AT4G13350)-AD [92] as 
negative and positive controls, respectively. (D) In vivo interaction between Mi-EFF1/Minc17998 and GmHub6 assessed by bimolecular fluorescence complementation (BiFC) assays. Fluorescence (YFP) images were acquired after the coexpression of the binary vectors pSITE BiFC cEFYP (GU734652) and nEYFP (GU734651) with the 35S:GmHub6-cYFP + 35S:Mi-EFF1/Minc17998 -nYFP fusion proteins in N. tabacum leaves. Negative controls were based on the empty vectors used in BiFC assays. Images are representative samples from three independent biological repeats. Scale bars are $20 \mu \mathrm{m}$. 


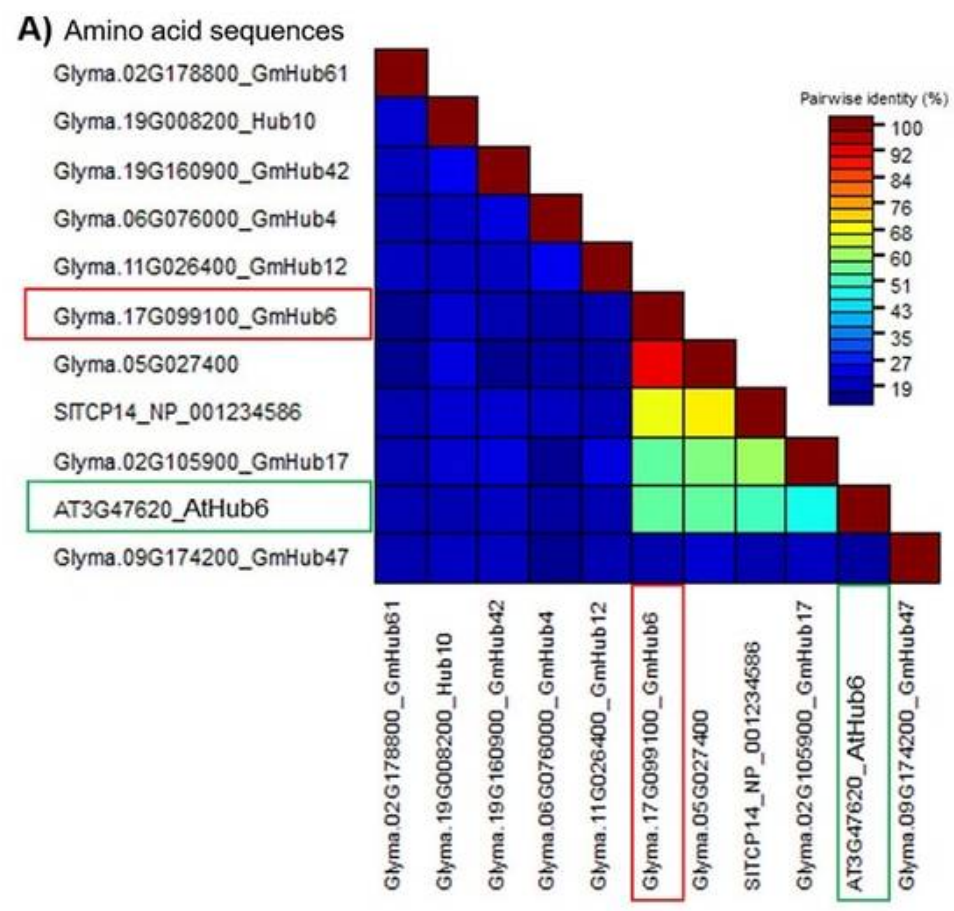

D)

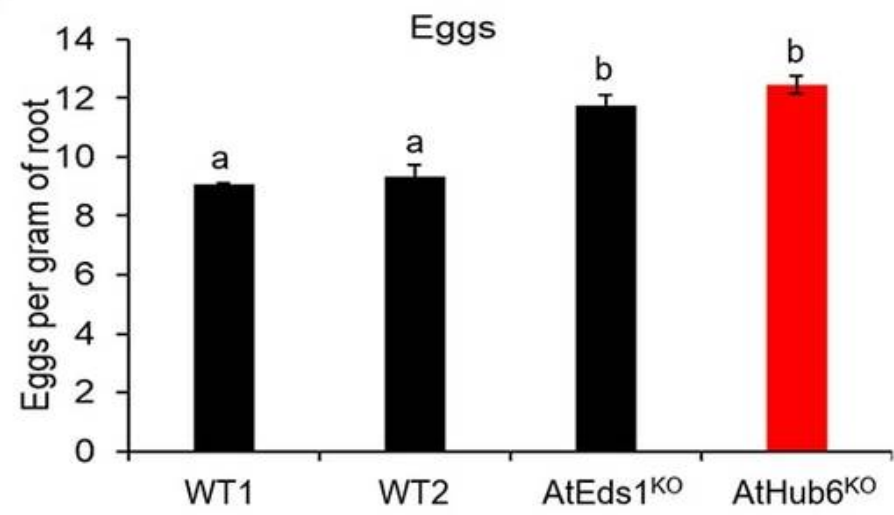

F)

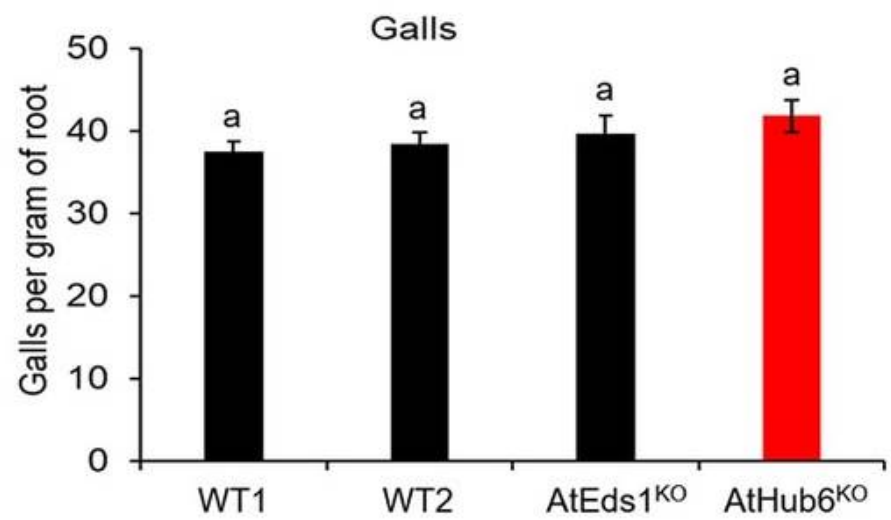

B) Amino acid sequences

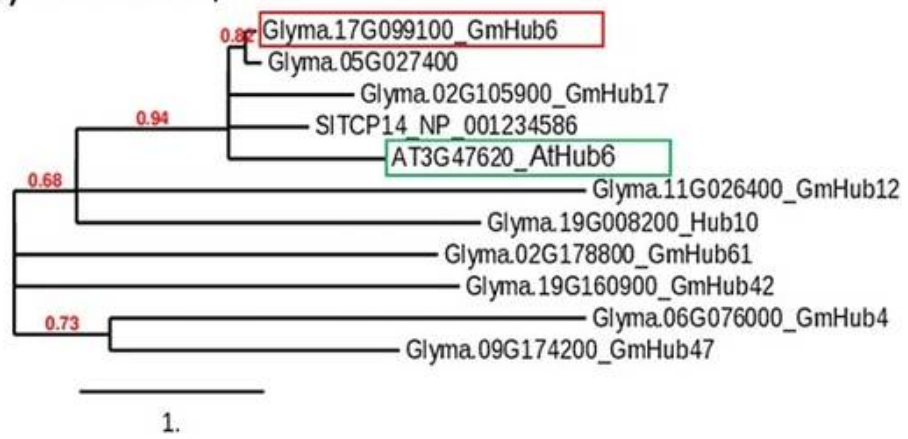

C)

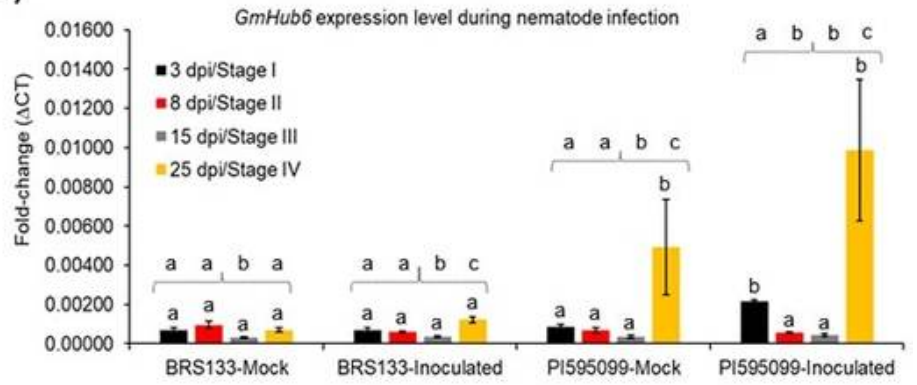

E)

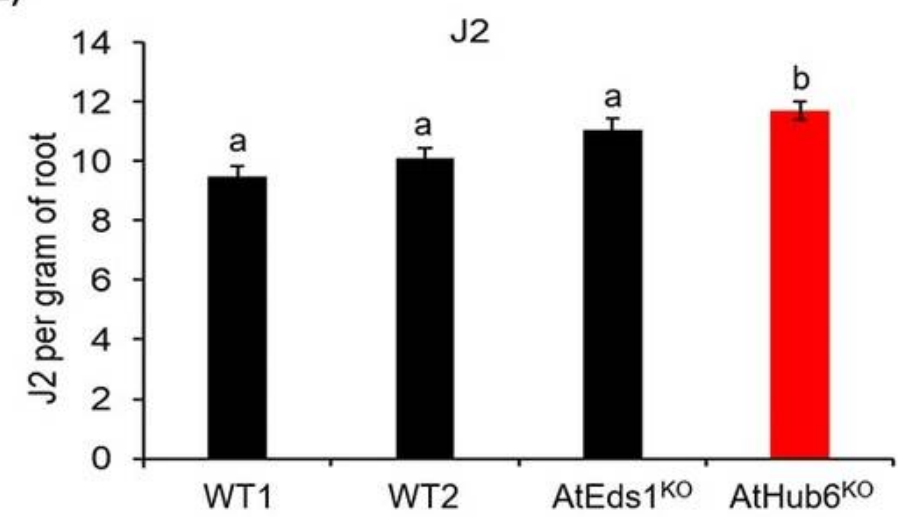

G)

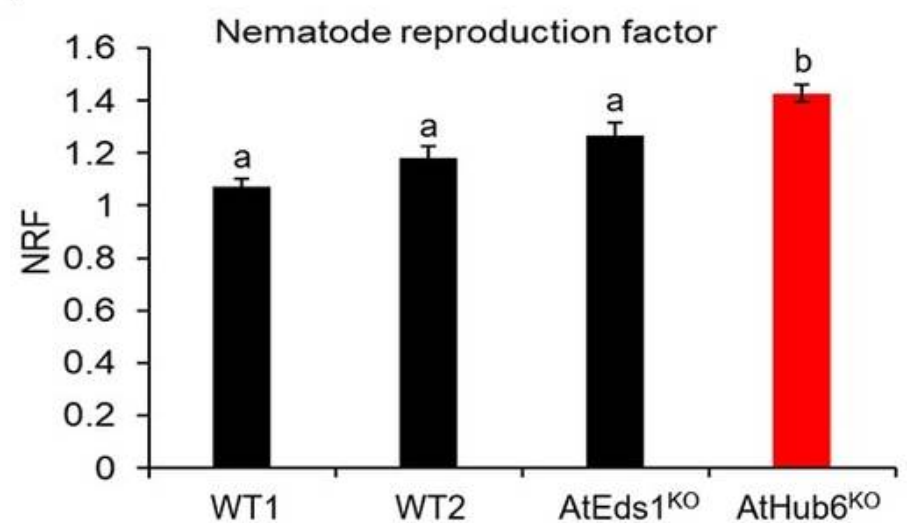

Figure 3

In silico analysis and GmHub6 (Glyma.17G099100) gene expression profile in soybean roots during M. incognita infection. (A) Pairwise sequence identity matrix from amino acid sequences generated using Sequence Demarcation Tool version 1.2 software [79]. In addition, GmHub4 (Glyma.06G076000), 
GmHub6 (Glyma.17G099100), GmHub12 (Glyma.11G026400), GmHub17 (Glyma.02G105900), GmHub42 (Glyma.19G160900), GmHub47 (Glyma.09G174200), GmHub61 (Glyma.02G178800) (Table 1), one putative homologous protein of GmHub6 (Table 2), and Solanum lycopersicum SITCP14 (NP_001234586) were included in this sequence analysis. (B) Evolutionary analysis of amino acid sequences generated by the Phylogeny.fr web service [80]. Red and green boxes are highlight the GmHub6 and AtHub6 proteins, respectively, which were studied in this work. Soybean gene sequences were retrieved from G. max Wm82.a2.v1 (BioProject: PRJNA19861) [84] via the Phytozome v.12 database [85], while the S. lycopersicum SITCP14 amino acid sequence (NP_001234586) was retrieved from the GenBank Database. (C) Expression profile of the GmHub6 gene in the axillary roots of the conventional soybean cultivars BRS133 (susceptible) and PI595099 (resistant), which are considered to present contrasting root-knot nematode resistance/susceptibility [94]. The expression profile was measured in the mock-inoculated and $\mathrm{M}$. incognita race 1-inoculated plants using RT-qPCR assays at 3, 8, 15, and 25 days postinoculation (dpi). The time points of $3,8,15$, and 25 dpi correspond to development stages I (opening of the second trifoliate), II (opening of the fourth trifoliate), III (opening of the sixth trifoliate in cultivar BRS133 and beginning of flowering in cultivar PI595099), and IV (beginning of flowering in cultivar BRS133 and the grain boot stage in cultivar PI595099) in the plants maintained under greenhouse conditions. The fold-change values were calculated using the 2- $\Delta \mathrm{CT}$ formula with the GmCYP18 gene as an endogenous reference gene (Table S1). Error bars represent confidence intervals corresponding to four biological replicates (each biological replicate was composed of four plants). Different letters in the graph bars indicate significant differences based on Tukey's test at the $5 \%$ level of significance.

Susceptibility of the A. thaliana AtHub6 (AT3G47620; attcp14-5; GK-611C04/CS458588) mutant (T-DNA insertion) line to $M$. incognita race 3 compared to the A. thaliana Col-0 ecotype (wild-type; WT) and the null mutant line for the enhanced disease susceptibility 1 (AT3G48090; Eds1; SALK_034340) gene. (D) Number of eggs per gram of roots, (E) number of M. incognita J2 per gram of roots, $(F)$ number of galls per gram of roots, and (G) nematode reproduction factor (NRF) in A. thaliana WT (AtWT1 and AtWT2), A. thaliana AtEds1 mutant (AtEds1KO), and A. thaliana AtHub6 mutant (AtHub6KO). Error bars represent confidence intervals corresponding to three technical replicates (D, E, and $G)$ or to each plant evaluated $(F)$, while each treatment was composed of 15 to 20 plants. Different letters on the graph bars indicate significant differences based on Tukey's test at the $5 \%$ level of significance.

\section{Supplementary Files}

This is a list of supplementary files associated with this preprint. Click to download.

- FigureS1.tif

- Figures2.tif

- FigureS3.tif

- Additionalfile1.docx 